\title{
Novel Double-Hit Model of Radiation and Hyperoxia-Induced Oxidative Cell Damage Relevant to Space Travel
}

\author{
Ralph A. Pietrofesa ${ }^{1}$, Anastasia Velalopoulou ${ }^{1}$, Stacey L. Lehman ${ }^{2}$, Evguenia Arguiri ${ }^{1}$, \\ Pantelis Solomides ${ }^{1}$, Cameron J. Koch ${ }^{2}$, Om P. Mishra ${ }^{1}$, Constantinos Koumenis ${ }^{2}$, \\ Thomas J. Goodwin ${ }^{3}$ and Melpo Christofidou-Solomidou ${ }^{1, *}$
}

1 Division of Pulmonary, Allergy, and Critical Care Medicine and the Department of Medicine, University of Pennsylvania Perelman School of Medicine, 3450 Hamilton Walk, Edward J. Stemmler Hall 2nd Floor, Office Suite 227, Philadelphia, PA 19104, USA; ralphp@mail.med.upenn.edu (R.A.P.);

avela@mail.med.upenn.edu (A.V.); evguenia@mail.med.upenn.edu (E.A.); pantelis.solomides@temple.edu (P.S.); mishra.o@gmail.com (O.P.M.)

2 Department of Radiation Oncology, University of Pennsylvania Perelman School of Medicine, Philadelphia, PA 19104, USA; staceylehman87@gmail.com (S.L.L.); kochc@mail.med.upenn.edu (C.J.K.); costas.Koumenis@uphs.upenn.edu (C.K.)

3 The National Aeronautics and Space Administration (NASA) Johnson Space Center, Houston, TX 77058, USA; tgoodwin3@comcast.net

* Correspondence: melpo@mail.med.upenn.edu; Tel.: +1-215-573-9917; Fax: +1-215-573-4469

Academic Editor: Terrence Piva

Received: 8 February 2016; Accepted: 9 June 2016; Published: 16 June 2016

\begin{abstract}
Spaceflight occasionally requires multiple extravehicular activities (EVA) that potentially subject astronauts to repeated changes in ambient oxygen superimposed on those of space radiation exposure. We thus developed a novel in vitro model system to test lung cell damage following repeated exposure to radiation and hyperoxia. Non-tumorigenic murine alveolar type II epithelial cells (C10) were exposed to $>95 \% \mathrm{O}_{2}$ for $8 \mathrm{~h}$ only $\left(\mathrm{O}_{2}\right), 0.25$ Gy ionizing $\gamma$-radiation (IR) only, or a double-hit combination of both challenges $\left(\mathrm{O}_{2}+\mathrm{IR}\right)$ followed by $16 \mathrm{~h}$ of normoxia (ambient air containing $21 \% \mathrm{O}_{2}$ and $\left.5 \% \mathrm{CO}_{2}\right)(1$ cycle $=24 \mathrm{~h}, 2$ cycles $=48 \mathrm{~h})$. Cell survival, DNA damage, apoptosis, and indicators of oxidative stress were evaluated after 1 and 2 cycles of exposure. We observed a significant $(p<0.05)$ decrease in cell survival across all challenge conditions along with an increase in DNA damage, determined by Comet analysis and H2AX phosphorylation, and apoptosis, determined by Annexin- $\mathrm{V}$ staining, relative to cells unexposed to hyperoxia or radiation. DNA damage (GADD45 $\alpha$ and cleaved-PARP), apoptotic (cleaved caspase- 3 and BAX), and antioxidant (HO-1 and Nqo1) proteins were increased following radiation and hyperoxia exposure after 1 and 2 cycles of exposure. Importantly, exposure to combination challenge $\mathrm{O}_{2}+\mathrm{IR}$ exacerbated cell death and DNA damage compared to individual exposures $\mathrm{O}_{2}$ or IR alone. Additionally levels of cell cycle proteins phospho-p53 and p21 were significantly increased, while levels of CDK1 and Cyclin B1 were decreased at both time points for all exposure groups. Similarly, proteins involved in cell cycle arrest was more profoundly changed with the combination challenges as compared to each stressor alone. These results correlate with a significant 4- to 6-fold increase in the ratio of cells in G2/G1 after 2 cycles of exposure to hyperoxic conditions. We have characterized a novel in vitro model of double-hit, low-level radiation and hyperoxia exposure that leads to oxidative lung cell injury, DNA damage, apoptosis, and cell cycle arrest.
\end{abstract}

Keywords: cell cycle; DNA damage; extravehicular activity; hyperoxia; ionizing radiation; lung cell injury; oxidative stress; reactive oxygen species; and space exploration 


\section{Introduction}

Extravehicular activities (EVA) are required by astronauts during space travel and may pose potential health risks [1-4]. Astronauts are exposed to the outer space environment while performing EVAs, including routine maintenance during space flights [5]. During EVAs that typically last for 5-8 h, crewmembers use pressurized spacesuits to create a controlled internal environment [5]. While acute oxygen toxicity is carefully avoided by extensive training, the long term influence of multiple EVAs and ensuing cyclic exposures to hyperoxic and hypoxic conditions amidst hypobaric pressures [6] during pre-breathe training protocols, and thus human exploration missions, on lung function is not known. Considering that there will be an increased requirement for crew members to perform frequent EVAs as deep space exploration becomes a reality, conditions that could pose a risk to the safety and health of the crew must be identified and prevented by designing modified procedure protocols.

Lung complications occurring from prolonged space travel are not well characterized [7]. In addition to space radiation exposure, health risks are compounded by exposure to $100 \% \mathrm{O}_{2}$. Hyperbaric and hyperoxic conditions have been extensively studied in relation to decompression illness (DCI) in divers [8]. However, exposure to a unique spectrum of space radiation including galactic cosmic radiation (GCR) and solar particle events (SPE) $[9,10]$ adds an additional environmental risk that may affect lung tissue primed by repeat exposures to hyperoxia during preparation for and during exploration EVAs at hypobaric pressures. With the use of a mouse model to identify potential risks to lung tissues when exposed to conditions associated with space travel, we have characterized significant air space enlargement, lung inflammation, and cellular injury [11].

To address the knowledge gap regarding lung complications that result from the combined effects of repeat hyperoxia and radiation exposures, we established an in vitro model system to test these effects at the cellular level. We have recently developed a novel in vivo mouse model to study individual stressors such as hyperoxia or low levels of radiation exposures as well as the combinatorial effects of both stressors and demonstrated that low level radiation and hyperoxia exposure results in lung inflammation, fibrosis and oxidative tissue damage in mice $[12,13]$. The present study was designed to develop and characterize an in vitro model to investigate the underlying molecular mechanisms of double-hit-induced lung damage using murine pulmonary epithelial cell cultures under controlled atmospheric conditions. Our goal was to use this in vitro model to characterize potential pathways of cell damage and death that lead to deleterious changes in lung cells and ultimately impair lung function. Although such an in vitro model system lacks the important immune response system of an intact animal, known to contribute to radiation [14] and hyperoxia [15] damage, valuable information can be gained to provide insight to individual cell responses.

We hypothesized that lung epithelial cells exposed to hyperoxia and radiation will experience increased oxidative cell damage resulting from an increased production of reactive oxygen species (ROS) following hyperoxia and radiation exposure. Additionally, we hypothesized that lung epithelial cells exposed to the combined challenge of radiation and hyperoxia will experience increased cellular injury and impairment. In the present study, we evaluated lung epithelial cell viability, DNA damage, apoptosis, and indicators of oxidative stress in an in vitro model of radiation and hyperoxia exposure simulating challenges relevant to space travel.

\section{Results}

We have recently developed a novel in vivo murine model of repeated double-hit radiation and hyperoxia exposure relevant to space travel to identify potential acute and long term damaging effects in lung $[12,13]$. To address mechanisms underlying lung cell damage induced by exposure to radiation and hyperoxia, however, we developed an in vitro model system that permitted cell exposure to combination radiation and hyperoxia. 


\subsection{Novel Design of Airtight Chambers for in Vitro Exposures to Hyperoxia and Radiation}

Select stress conditions to lung tissues such as exposure to high oxygen levels [16] or to radiation [17], result in lung damage; however, there is no cell system that would allow the study of the joint stressor challenge at the cellular level. Repeated, short-duration hyperoxia $(8 \mathrm{~h})$, low-level radiation levels $(0.25 \mathrm{~Gy})$, or the combination of both challenges in lung epithelial cells was evaluated in a study design (Figure 1a) simulating exposures relevant to challenges encountered during space travel and the performance of multiple extravehicular activities. We used specially-constructed, airtight metal chambers that allowed radiation to penetrate, while keeping cells under controlled oxygen levels (Figure $1 \mathrm{~b}$ ) to simulate airway epithelial cell exposure during multiple, weekly EVAs performed by crewmembers. Cells were exposed to two cycles over the period of $24 \mathrm{~h}$ ( 1 cycle) and $48 \mathrm{~h}$ ( 2 cycles) and evaluated for diverse stress and cell damage biomarkers.

a

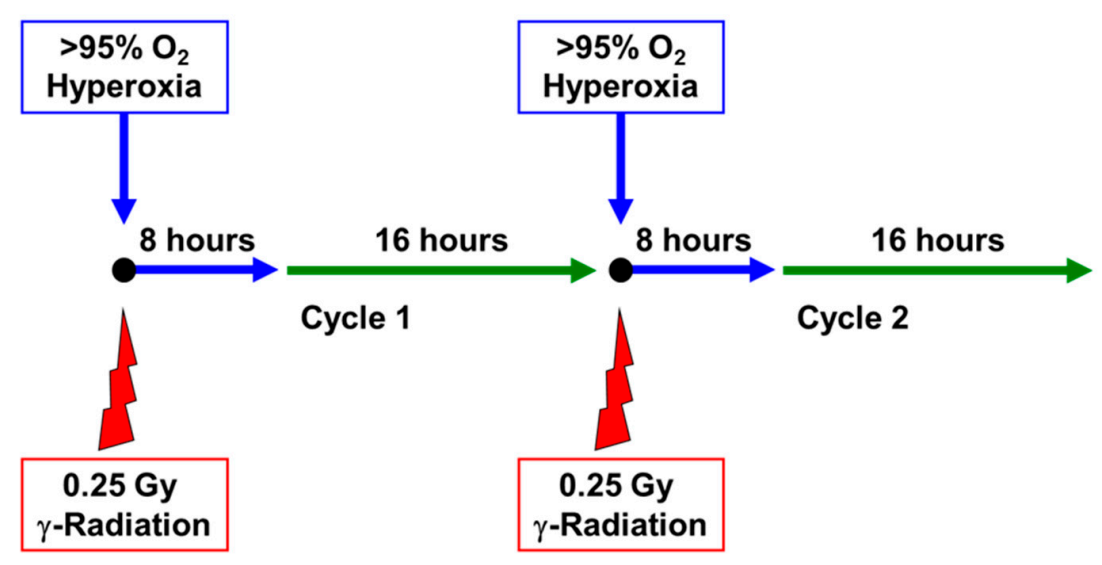

b

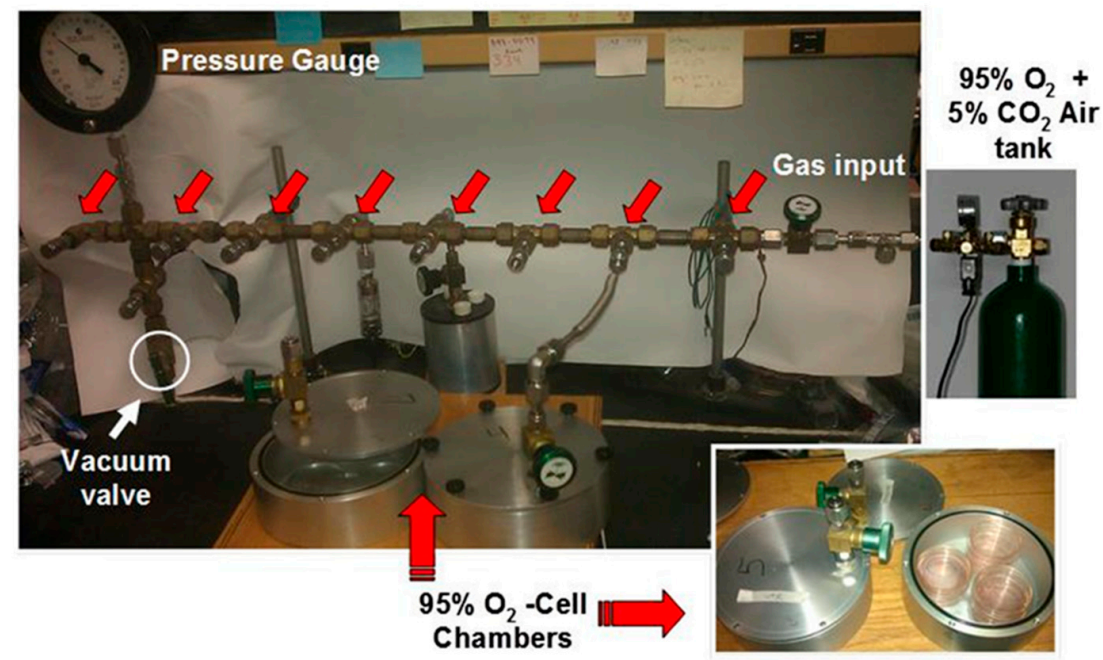

Figure 1. Experimental plan of in vitro cell exposure. (a) Non-tumorigenic murine alveolar type II epithelial cells (C10) were exposed to $100 \% \mathrm{O}_{2}$ for $8 \mathrm{~h}$ only $\left(\mathrm{O}_{2}\right), 0.25 \mathrm{~Gy}$ ionizing $\gamma$-radiation (IR) only, or a double-hit combination of both challenges $\left(\mathrm{O}_{2}+\mathrm{IR}\right)$ followed by $16 \mathrm{~h}$ of normoxia (21\% partial pressure of oxygen $\left(\mathrm{pO}_{2}\right)$ ) (1 cycle). This was repeated for 2 cycles and cells were harvested at the end of each 24 h cycle: 1 and 2 cycles of exposure corresponding to 24 and $48 \mathrm{~h}$, respectively; (b) Images displaying the experimental setup of in vitro cell exposure. Pictured are the chambers holding the $6 \mathrm{~cm}$ cell culture Petri dishes and the gas manifold allowing for $\mathrm{O}_{2}$ exposure. 
2.2. Cell Survival, Apoptosis, and Oxidative DNA Damage in Lung Epithelial Cells Exposed to Hyperoxia, Low-Level Radiation, and Double-Hit Combination Challenge

As anticipated, untreated pulmonary epithelial cells showed an increase in overall cell number after 24 and $48 \mathrm{~h}$ of incubation. However, after 2 cycles ( $48 \mathrm{~h}$ ) of exposure to challenge conditions, total cell numbers were significantly reduced compared to untreated controls $(p<0.05)$. Overall cell number was significantly $(p<0.05)$ reduced after 1 and 2 cycles of double-hit combination challenge of $\mathrm{O}_{2}+\mathrm{IR}$ exposure by $36 \%$ and $65 \%$, respectively, when compared to controls (Figure 2a).

\section{a}

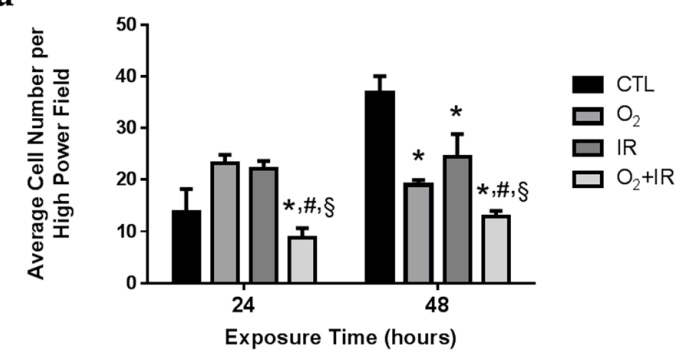

b

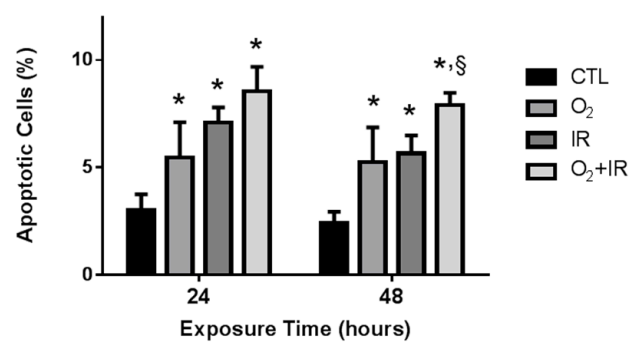

C

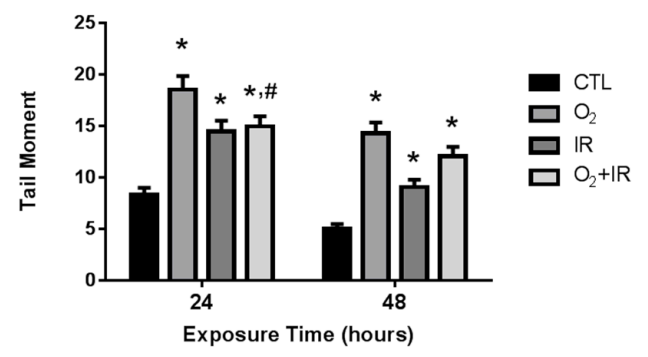

Figure 2. Determination of cell survival, apoptosis, and oxidative DNA damage in lung epithelial cells exposed to hyperoxia, radiation, and double-hit combination challenge. Non-tumorigenic murine alveolar type II epithelial cells (C10) were evaluated after 1 and 2 cycles of hyperoxia and radiation exposure for (a) cell survival using light microscopy (200x); (b) apoptotic bodies using fluorescent DAPI staining; and (c) DNA damage by comet assay analysis. Data are presented as mean \pm SEM. ${ }^{*} p<0.05$ for each exposure condition as it compares with the unexposed control (CTL) in the same respective time-group; ${ }^{\#} p<0.05$ for significant differences between $\mathrm{O}_{2}$-alone compared to $\mathrm{O}_{2}+\mathrm{IR}$; $\S p<0.05$ for significant differences between IR-alone compared to $\mathrm{O}_{2}+\mathrm{IR}$.

Murine pulmonary epithelial cells exposed to challenge conditions were analyzed for DNA damage via comet analysis and apoptosis via quantification of apoptotic bodies using fluorescent microscopy. Exposure of lung epithelial cells in the chambers to radiation and hyperoxia significantly $(p<0.05)$ induced oxidative stress, damaged DNA, triggered apoptotic signaling, and ultimately lead to programmed cell death. All challenge conditions $\left(\mathrm{O}_{2}, \mathrm{IR}, \mathrm{O}_{2}+\mathrm{IR}\right)$ significantly induced DNA damage $(p<0.05)$ as measured by comet analysis, which quantifies DNA double strand breaks (Figure 2c). This effect was noted both after 1 cycle $(24 \mathrm{~h})$ and 2 cycles $(48 \mathrm{~h})$ of exposure. Elevated amounts of irreparable DNA damage led to an increase in apoptosis $(p<0.03)$, measured by the quantification of apoptotic bodies, observed after 1 and 2 cycles of hyperoxia and radiation exposure (Figure $2 b$ ). 
Double-hit $\left(\mathrm{O}_{2}+\mathrm{IR}\right)$ combination challenge significantly $(p<0.05)$ increased the percentage of apoptotic cells from $2 \%$ to $8 \%$. We observed exposure-induced reductions in overall cell survival that correlate with increased DNA damage and subsequent apoptosis.

\subsection{Double-Hit Combination Challenge Switches Cell Death to Apoptosis in Lung Epithelial Cells}

We investigated the cell death induced in non-tumorigenic murine alveolar type II epithelial cells $48 \mathrm{~h}$ ( 2 cycles) after exposure to hyperoxia, low-level irradiation and double-hit combined challenges using Annexin V-FITC and PI staining (Figure 3). Hyperoxia induced a statistically significant $(p<0.001)$ increase in necrotic cell death compared to untreated control (from $2.23 \%$ to $15.03 \%$ ) whereas the percentage of necrotic cells in the irradiated cohort were $6.06 \%$ (Figure 3a,b). Interestingly, the double-hit combined exposure to hyperoxia and irradiation switched the profile of cell death from necrosis to apoptosis, as cells exposed to both challenges showed $6.53 \%$ of apoptosis when necrosis was maintained at $2.45 \%$, close to baseline levels of the untreated cells (Figure 3b).

a
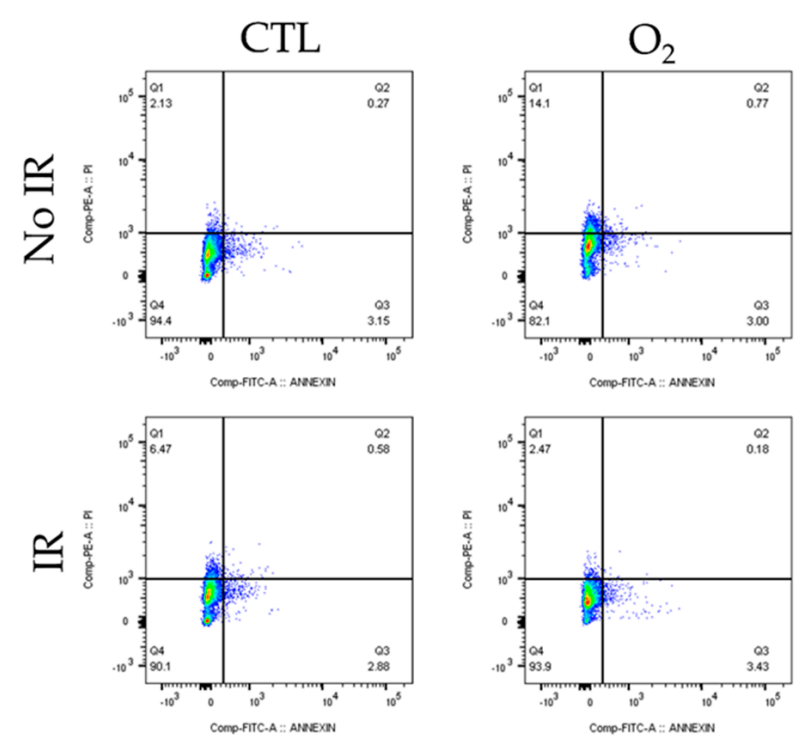

b

\begin{tabular}{cccc}
\hline & Viable & Apoptotic & Necrotic \\
\hline $\mathrm{CTL}$ & $95.23 \pm 1.2$ & $2.50 \pm 0.49$ & $2.23 \pm 0.95$ \\
\hline $\mathrm{O}_{2}$ & $80.57 \pm 1.34$ & $4.39 \pm 0.87$ & $15.03 \pm 0.55^{*}$ \\
\hline $\mathrm{IR}$ & $91.20 \pm 0.91$ & $2.79 \pm 0.37$ & $6.06 \pm 0.92^{*}$ \\
\hline $\mathrm{O}_{2}+\mathrm{IR}$ & $91.00 \pm 3.46$ & $6.53 \pm 2.98$ & $2.45 \pm 0.54^{*, \S}$ \\
\hline
\end{tabular}

Figure 3. Flow cytometric analysis of apoptosis/necrosis stained with Annexin V-FITC and PI in lung epithelial cells $48 \mathrm{~h}$ ( 2 cycles) after exposure to hyperoxia, radiation, and double-hit combination challenge. Non-tumorigenic murine alveolar type II epithelial cells (C10) were evaluated after 2 cycles of hyperoxia and radiation exposure and evaluated by flow cytometric analysis of apoptosis/necrosis stained with Annexin V-FITC and PI. (a) Representative flow cytograms depicting Annexin V-FITC and PI staining showing the distribution of necrotic and apoptotic cells; (b) Percentages (\%) of apoptotic (positive Annexin V-FITC) and necrotic (negative Annexin V-FITC and positive PI) cells in every cohort, as compared to untreated cells. Data are represented as the mean $\pm \mathrm{SEM}$. ${ }^{*} p<0.05$ for each exposure condition as it compares with the unexposed control (CTL); ${ }^{\#} p<0.05$ for significant differences between $\mathrm{O}_{2}$-alone compared to $\mathrm{O}_{2}+\mathrm{IR} ; \S p<0.05$ for significant differences between IR-alone compared to $\mathrm{O}_{2}+\mathrm{IR}$. 
2.4. Alterations in Cell Cycle Progression in Lung Epithelial Cells Exposed to Repeat Cycles of Hyperoxia, Radiation, and Double-Hit Combination Challenge

We further investigated the observed increases in DNA damage and apoptosis to determine specific alterations in cell cycle progression induced by exposure to hyperoxia and radiation. No effects on the cell cycle were observed in any of the treatment groups after $24 \mathrm{~h}$ of challenge exposure (Figure 4 ). After $48 \mathrm{~h}$ of hyperoxia, cells underwent G2/M arrest, as evidenced by an increase in the percentage of cells in the G2/M phase of the cell cycle with a concomitant decrease in the percentage of cells in the G1 phase of the cell cycle (Figure 4a,b). These results are quantified as the G2/G1 ratio (Figure 4c). Forty-eight hours of hyperoxia treatment resulted in a statistically significant 5.9-fold increase $(p<0.05)$ in the G2/G1 ratio. Ionizing radiation alone had no effect on the G2/G1 ratio at $48 \mathrm{~h}$. However, addition of ionizing radiation to hyperoxia treatment appeared to decrease $(p<0.05)$ the degree of G2/M arrest induced by hyperoxia-alone. The combination treatment caused a significant 4.1-fold increase $(p<0.05)$ in the G2/G1 ratio, as opposed to the 5.9-fold increase induced by hyperoxia alone.

\section{a}
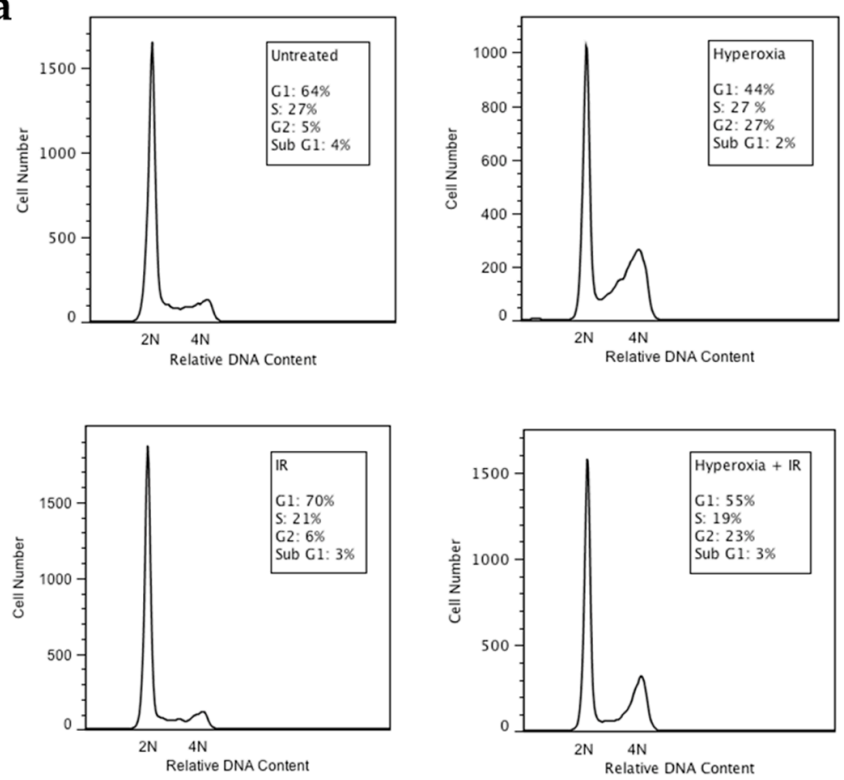

b

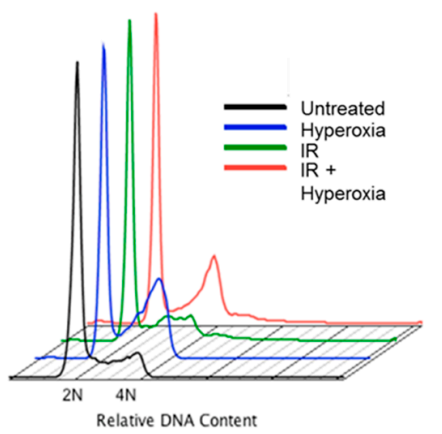

C

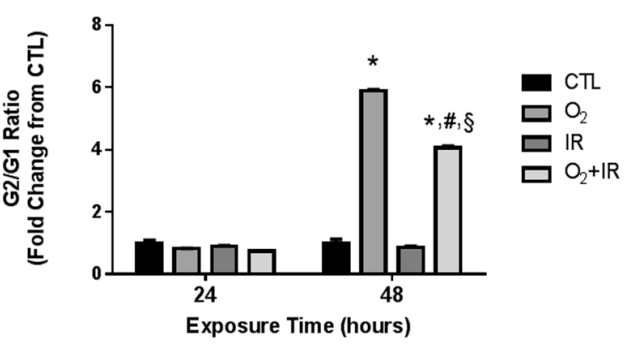

Figure 4. Hyperoxia and Combination Exposure Induces Cell Cycle Arrest. Non-tumorigenic murine alveolar type II epithelial cells (C10) were evaluated after 1 and 2 cycles of hyperoxia and radiation exposure and evaluated by flow cytometry for DNA content. (a,b) Cell cycle histograms display the DNA content (diploid or $2 \mathrm{~N}$; tetraploid or $4 \mathrm{~N}$ ) after 2 cycles $(48 \mathrm{~h})$ of exposure and (c) data are expressed as the ratio of G2 to G1. Data are presented as mean \pm SEM. ${ }^{*} p<0.05$ for each exposure condition as it compares with the unexposed control (CTL) in the same respective time-group; ${ }^{*} p<0.05$ for significant differences between $\mathrm{O}_{2}$-alone compared to $\mathrm{O}_{2}+\mathrm{IR} ;{ }^{\S} p<0.05$ for significant differences between IR-alone compared to $\mathrm{O}_{2}+\mathrm{IR}$. 
2.5. Modulation of Key Cell Cycle Signaling Protein Levels in Lung Epithelial Cells Exposed to Hyperoxia, Radiation, and Double-Hit Combination Challenge

Cell cycle signaling proteins control the cell cycle checkpoints for either transition to the next phase or cell death [18-23]. In these studies, we focused on determining the effect of hyperoxia and radiation on select key components of G2/M phase transition. Mouse pulmonary epithelial cells exposed to challenge conditions were evaluated by western blotting for p21 (Figure 5a,b); an inhibitor of the CDK1/cyclin B1 complex, CDK1 (Figure 5a,c), Cyclin B1 (Figure 5a,d), and phospho-p53 (Figure 5a,e). After just 1 cycle $(24 \mathrm{~h})$ of challenge exposure, increased p21 protein expression was detected for all challenge conditions and remained elevated after $48 \mathrm{~h}$ (Figure 5b) with increased levels of p21 among $\mathrm{O}_{2}+$ IR exposure $(p<0.05)$ compared to $\mathrm{O}_{2}$-alone after $24 \mathrm{~h}$. The expression of CDK1 (Figure $5 \mathrm{c}$ ) and cyclin B1 (Figure $5 \mathrm{~d}$ ) was significantly $(p<0.01)$ decreased in the double-hit combination challenge, compared to CTL, $\mathrm{O}_{2}$-alone, and IR-alone, following the first cycle of exposure and remained low after $48 \mathrm{~h}$ of exposure. Levels of phosphorylated p53 (Figure 5d) were elevated after 1 and 2 cycles of exposure across all challenge conditions. In the double-hit combination challenge group, the increased expression of p21 and phospho-p53 proteins, and decreased CDK1 and Cyclin B1 expression, as indices of cell cycle arrest, correlate with the observed increase in apoptotic cell death (see Figure 2b).

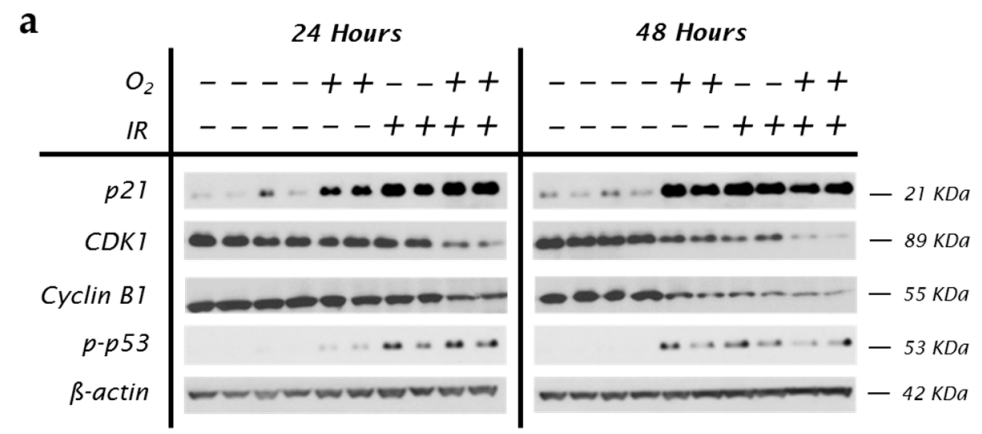

b

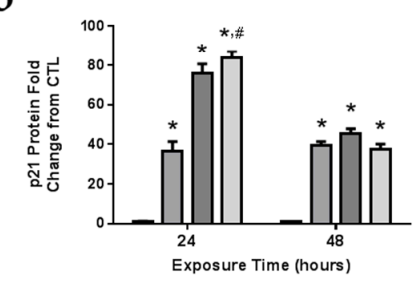

d

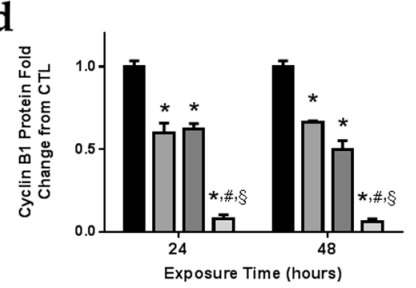

C

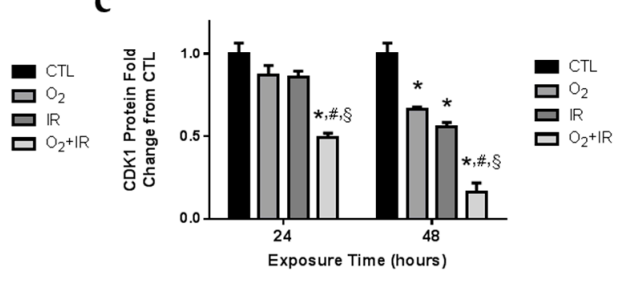

e

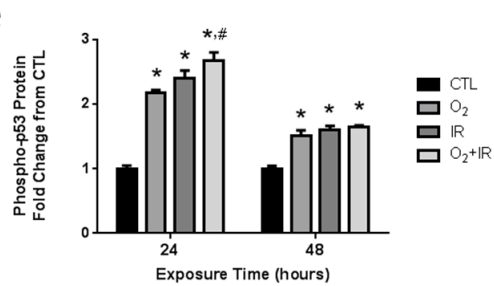

Figure 5. Hyperoxia and radiation exposure induce changes in cell cycle proteins. Non-tumorigenic murine alveolar type II epithelial cells (C10) were evaluated after 1 and 2 cycles of hyperoxia and radiation exposure and evaluated by (a) western blotting for p21, CDK1, and Cyclin B1, and phospho-p53. Densitometric analysis of band intensity for (b) p21; (c) CDK1; (d) Cyclin B1; and (e) phospho-p53 was normalized to $\beta$-actin and values are expressed as fold change from CTL. Data are presented as mean \pm SEM. ${ }^{*} p<0.05$ for each exposure condition as it compares with the unexposed control (CTL) in the same respective time-group; ${ }^{\#} p<0.05$ for significant differences between $\mathrm{O}_{2}$-alone compared to $\mathrm{O}_{2}+\mathrm{IR} ; \S p<0.05$ for significant differences between IR-alone compared to $\mathrm{O}_{2}+\mathrm{IR}$. 
2.6. H2AX Phosphorylation due to DNA Damage in Pulmonary Epithelial Cells Exposed to Repeat Cycles of Radiation, Hyperoxia or Double-Hit Combination Challenge

To assess DNA double strand break damage following exposure to hyperoxia and radiation, we performed flow cytometric analysis for the detection of H2AX phosphorylation at Serine 139 (Figure 6), due to exposure of pulmonary epithelial cells to radiation, hyperoxia or the combination of the two conditions. A significant 8.4-fold increase of the H2AX phosphorylation was observed when cells were treated for $48 \mathrm{~h}$ or two cycles $\left(>95 \% \mathrm{O}_{2}\right.$ for $8 \mathrm{~h}$ per cycle) of hyperoxia whereas exposure to two doses of 0.25 Gy ionizing radiation induced a 1.85-fold increase, as compared to untreated cells. Two cycles of the double-hit combination of both challenges $\left(\mathrm{O}_{2}+\mathrm{IR}\right)$ led to a statistically significant increase in H2AX phosphorylation by 4.67-fold $(p<0.001)$ compared to CTL (Figure $6 \mathrm{a}, \mathrm{b}$ ).

a
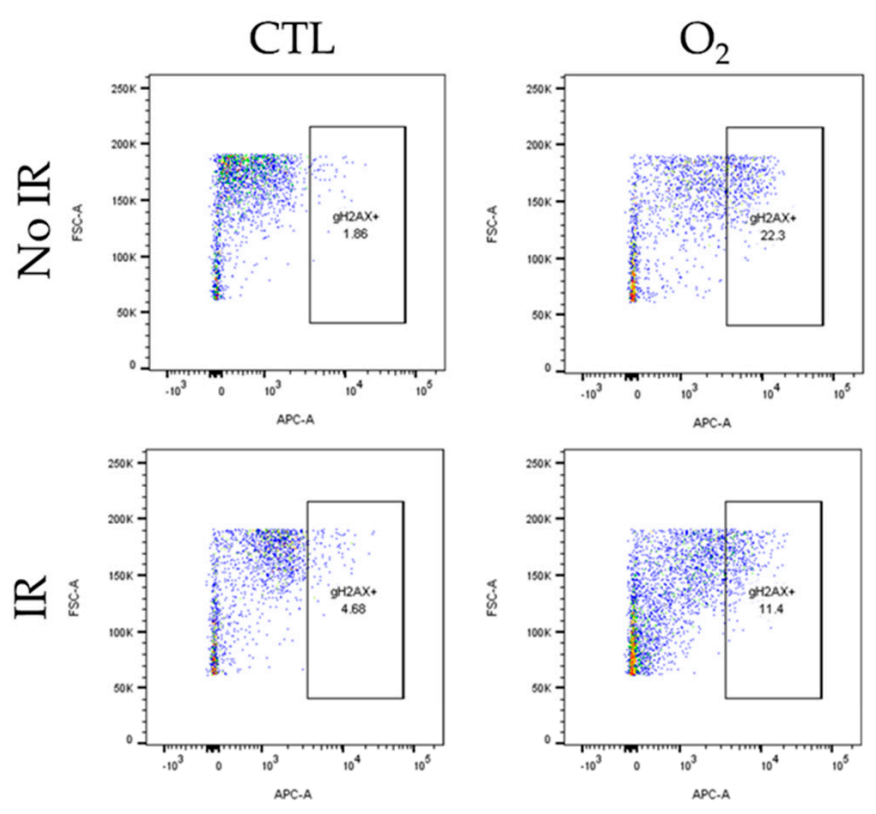

b

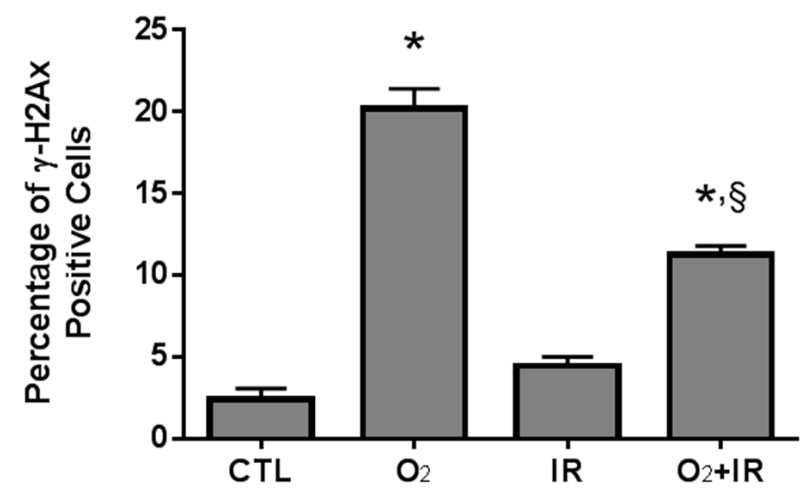

Figure 6. Flow cytometric analysis of H2AX phosphorylation in lung epithelial cells $48 \mathrm{~h}$ (2 cycles) after exposure to hyperoxia, radiation, and double-hit combination challenge. Non-tumorigenic murine alveolar type II epithelial cells (C10) were evaluated after 2 cycles of hyperoxia and radiation exposure and evaluated by flow cytometric analysis of $\gamma \mathrm{H} 2 \mathrm{AX}$ and PI. (a) Representative flow cytograms depicting anti- $\gamma \mathrm{H} 2 \mathrm{AX}$ (Serine 139) labeling of cells under hyperoxic conditions and IR; (b) Levels of $\mathrm{H} 2 \mathrm{AX}$ phosphorylation represented by the percentages (\%) of positive stained C10 cells in every cohort. Data are represented as the mean \pm SEM. ${ }^{*} p<0.05$ for each exposure condition as it compares with the unexposed control (CTL); ${ }^{\S} p<0.05$ for significant differences between IR-alone compared to $\mathrm{O}_{2}+\mathrm{IR}$. 
2.7. Gene Expression Changes Related to DNA Damage and Apoptosis in Pulmonary Epithelial Cells Exposed to Repeat Cycles of Radiation, Hyperoxia or Double-Hit Combination Challenge

We evaluated the expression levels of $G A D D 45 \alpha$ (a gene encoding a protein that functions as a cellular sensor of genotoxic stress), survivin (a gene encoding a protein that functions as an inhibitor of apoptosis (IAP)), and BAX (a gene encoding a protein that functions to promote apoptosis). As an IAP, survivin is capable of binding to caspase-3 and thus negatively regulates apoptotic signaling [24]. Also, survivin gene expression is negatively regulated by p53 [25], and serves as a successful biomarker of genotoxic stress and subsequent apoptotic signaling. We asked whether gene expression changes of GADD $45 \alpha$, survivin, and BAX would correlate with the observation of increased DNA damage and apoptotic cell death. Indeed, all challenge conditions in vitro induced significant $(p<0.05)$ increases in GADD $45 \alpha$ gene expression levels after 1 and 2 cycles of exposure (Figure 7a). Conversely, we determined significant $(p<0.05)$ decreases in survivin gene expression (Figure $7 \mathrm{~b}$ ), while increasing mRNA levels of pro-apoptotic BAX (Figure 7c). The double-hit combination challenge $\left(\mathrm{O}_{2}+\mathrm{IR}\right)$ group had the highest reduction in survivin gene expression at all exposure times ( 24 and $48 \mathrm{~h}$ ), with a significant $(p<0.05)$ further decrease in survivin gene expression compared to $\mathrm{O}_{2}$ or IR exposure alone, while the exposure to hyperoxia alone and hyperoxia plus radiation induced marked increases in BAX expression after 1 and 2 cycles of exposure.

a

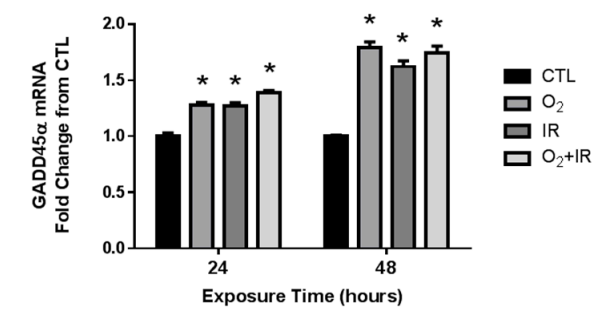

b

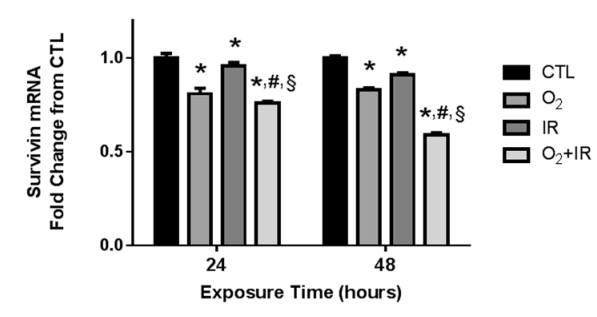

c

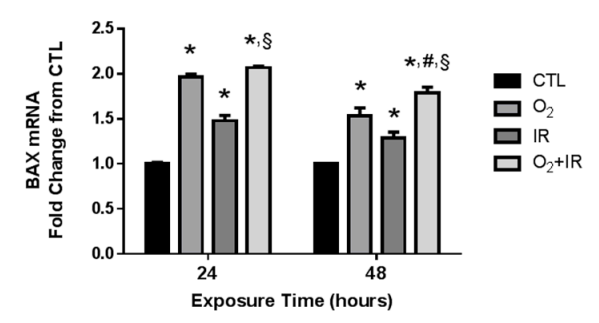

Figure 7. Determination of apoptosis-associated gene expression changes in lung epithelial cells exposed to hyperoxia, radiation, and double-hit combination challenge. Non-tumorigenic murine alveolar type II epithelial cells (C10) were evaluated after 1 and 2 cycles of hyperoxia and radiation exposure and evaluated by quantitative real-time PCR analysis for (a) GADD $45 \alpha$; (b) Survivin; and (c) BAX gene expression. Levels of target gene mRNA were normalized to $18 \mathrm{~S}$ ribosomal RNA and values are expressed as the mean fold change from CTL. Data are presented as mean \pm SEM. ${ }^{*} p<0.05$ for each exposure condition as it compares with the unexposed control (CTL) in the same respective time-group; ${ }^{\#} p<0.05$ for significant differences between $\mathrm{O}_{2}$-alone compared to $\mathrm{O}_{2}+\mathrm{IR} ; \S p<0.05$ for significant differences between IR-alone compared to $\mathrm{O}_{2}+\mathrm{IR}$. 
2.8. Expression of Apoptotic and DNA Damage-Induced Proteins in Lung Epithelial Cells Exposed to Hyperoxia, Radiation, and Double-Hit Combination Challenge

Murine pulmonary epithelial cells exposed to challenge conditions were evaluated by western blotting for GADD45 $\alpha$ (Figure 8a,b); a DNA damage-inducible protein that triggers apoptotic signaling [26-28], cleaved-PARP (Figure 8a,c); a key target enzyme for DNA repair following DNA damage [29,30], cleaved caspase-3 (Figure 8a,d), and BAX (Figure 8a,e). After just 1 cycle (24 h) of challenge exposure, increased GADD $45 \alpha$ and cleaved-PARP protein expression was detected for all challenge conditions with the double-hit combination challenge of $\mathrm{O}_{2}+\mathrm{IR}$ showing the greatest effect after 1 exposure cycle; significant elevations above untreated cells and $\mathrm{O}_{2}$ and IR exposure alone. Increased DNA damage and apoptosis were observed in the combination challenge, correlating with increased levels of cleaved-PARP and GADD $45 \alpha$. Levels of cleaved caspase-3, and BAX were significantly $(p<0.05)$ elevated following exposure to all challenge conditions after 1 and 2 cycles of exposure.

a

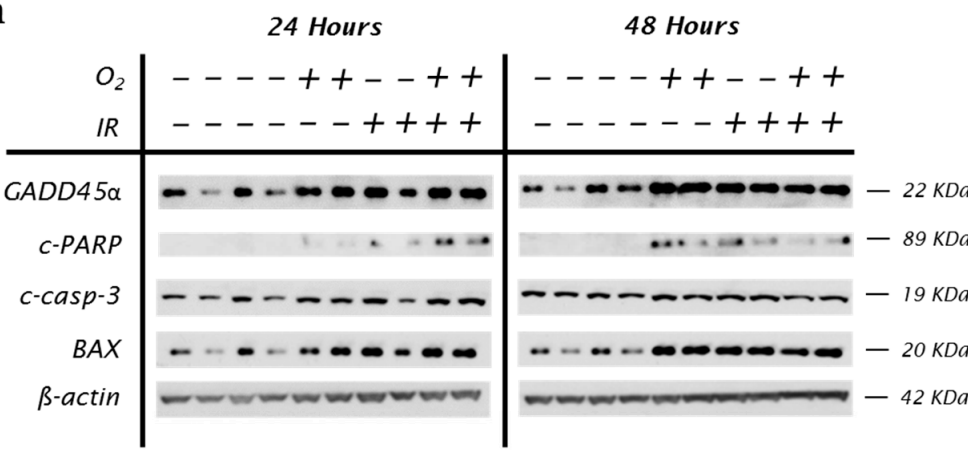

b

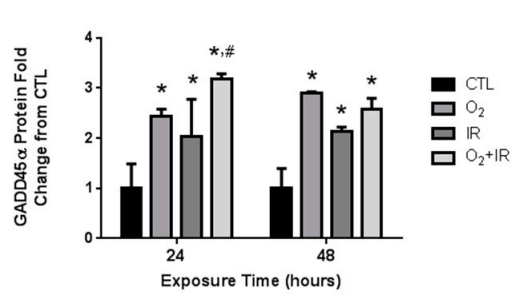

d

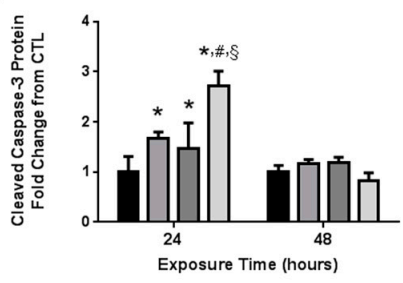

C

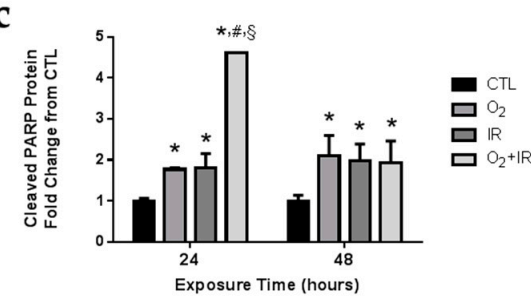

e

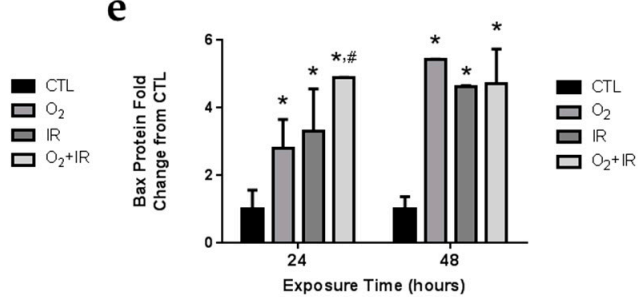

Figure 8. Determination of apoptosis and genotoxic stress in lung epithelial cells exposed to hyperoxia, radiation, and double-hit combination challenge. Non-tumorigenic murine alveolar type II epithelial cells (C10) were evaluated after 1 and 2 cycles of hyperoxia and radiation exposure and evaluated by (a) western blotting for GADD45 $\alpha$, cleaved-PARP, cleaved caspase-3, and BAX. Densitometric analysis of band intensity for (b) GADD45 $\alpha$; (c) cleaved-PARP; (d) cleaved caspase-3; and (e) BAX was normalized to $\beta$-actin and values are expressed as fold change from CTL. Data are presented as mean \pm SEM. ${ }^{*} p<0.05$ for each exposure condition as it compares with the unexposed control (CTL) in the same respective time-group; ${ }^{\#} p<0.05$ for significant differences between $\mathrm{O}_{2}$-alone compared to $\mathrm{O}_{2}+\mathrm{IR} ; \S p<0.05$ for significant differences between IR-alone compared to $\mathrm{O}_{2}+\mathrm{IR}$. 
2.9. Exposure to Repeated Cycles of Hyperoxia, Radiation, and Double-Hit Combination Challenge Induces the Expression of Key Antioxidant Enzymes in Pulmonary Epithelial Cells

Antioxidant enzymes, such as heme oxygenase-1 (HO-1) and NADPH: quinone oxidoreductase-1 (Nqo1), are induced by select challenges that alter the oxidative state of the cell and are indicative of conditions of oxidative stress. Both hyperoxia and radiation promote the generation of free radicals and reactive oxygen species (ROS). We evaluated hyperoxia and radiation-induced changes in $\mathrm{HO}-1$ (Figure 9a) and Nqo1 (Figure 9b) antioxidant mRNA levels in pulmonary epithelial cells after 1 and 2 cycles of exposure. Levels of HO-1 and Nqo1 mRNA were elevated after 1 cycle of exposure to hyperoxia and radiation. Gene expression of HO-1 was significantly $(p<0.05)$ increased across all exposure groups, with the greatest increase in mRNA levels occurring after $48 \mathrm{~h}$ of exposure. Protein levels of HO-1 were significantly increased $(p<0.05)$ in all exposure groups after 1 and 2 cycles of exposure, with the greatest induction of HO-1 protein expression (5.8- and 6.9-fold increase over CTL) occurring in cells exposed to both challenge conditions (Figure 9c,d). In addition, protein levels of Nqo1 were similarly increased over control in pulmonary epithelial cells exposed to hyperoxia, radiation, and combination challenge (Figure 9c,e). Importantly, exposure to combined hyperoxia and radiation challenges led to significantly $(p<0.05)$ higher levels of both HO-1 and Nqo1 compared to single challenge exposure to hyperoxia or radiation-alone.

a
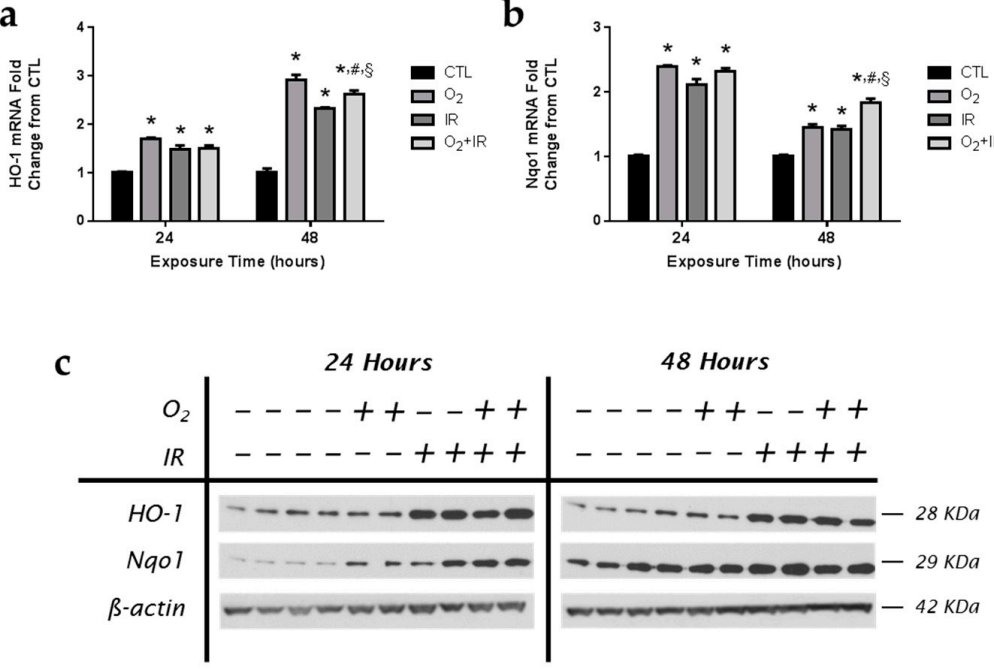

d

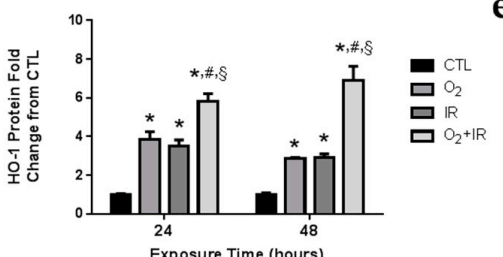

b
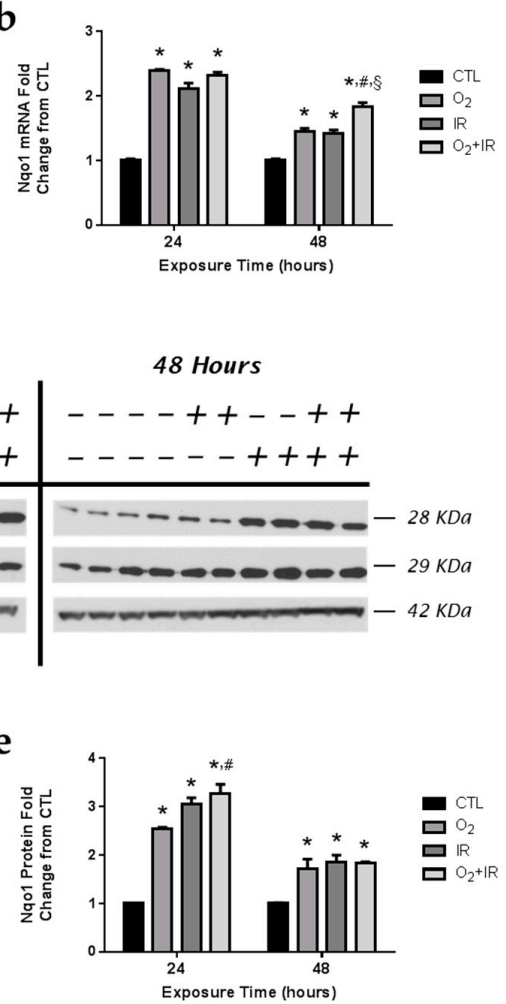

Figure 9. Exposure to hyperoxia, radiation, and double-hit combination challenge induces expression of antioxidant enzymes. Non-tumorigenic murine alveolar type II epithelial cells (C10) were evaluated after 1 and 2 cycles of hyperoxia and radiation exposure and evaluated by qPCR analysis of (a) HO-1 and (b) Nqo1 mRNA levels and by (c) western blotting for HO-1 and Nqo1. Levels of target gene mRNA were normalized to $18 \mathrm{~S}$ ribosomal RNA and values are expressed as the mean fold change from CTL. Densitometric analysis of band intensity for (d) HO-1 and (e) Nqo1 was normalized to $\beta$-actin and values are expressed as fold change from CTL. Data are presented as mean \pm SEM. ${ }^{*} p<0.05$ for each exposure condition as it compares with the unexposed control (CTL) in the same respective time-group; ${ }^{\#} p<0.05$ for significant differences between $\mathrm{O}_{2}$-alone compared to $\mathrm{O}_{2}+\mathrm{IR} ; \S^{\S} p<0.05$ for significant differences between IR-alone compared to $\mathrm{O}_{2}+\mathrm{IR}$. 
2.10. Expression of Apoptotic and DNA Damage-Induced Proteins in Lung Epithelial Cells Exposed to Hyperoxia, Radiation, and Double-Hit Combination Challenge

Similar to the reported findings in C10 epithelial cells exposed to similar challenge conditions, we evaluated the expression levels of GADD45 $\alpha$, Survivin, and BAX in murine lung tissues exposed to three cycles of hyperoxia $(8 \mathrm{~h})$ and radiation $(0.25 \mathrm{~Gy}$ total body irradiation) exposure. Exposure to challenge conditions led to significant $(p<0.05)$ elevations in GADD45 $\alpha$ and BAX mRNA levels (Figure 10). Importantly, the combined challenge exposure $\left(\mathrm{O}_{2}+\mathrm{IR}\right)$ led to a significantly $(p<0.05)$ further increase in the expression of both GADD $45 \alpha$ and $B A X$ compared to exposure to hyperoxia or radiation-alone. Furthermore, mRNA levels of Survivin were reduced by all challenge conditions ( $41 \%$, $20 \%$, and $49 \%$ decreased from CTL exposed mice for $\mathrm{O}_{2}, \mathrm{IR}$, and $\mathrm{O}_{2}+\mathrm{IR}$ exposure, respectively).

a

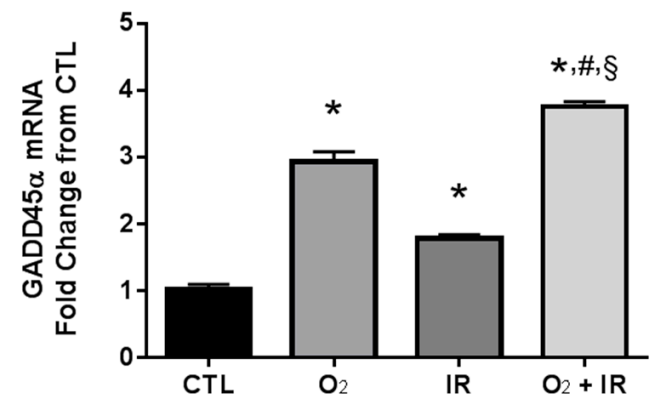

b

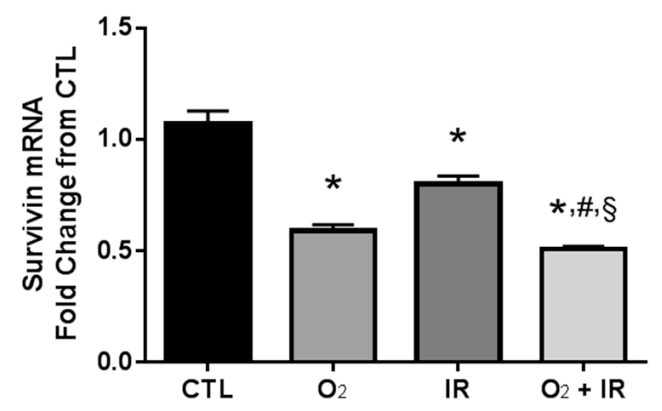

C

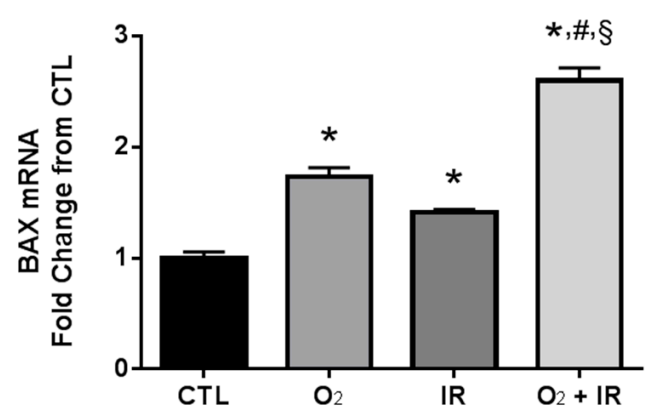

Figure 10. Evaluation of the effect of hyperoxia, radiation, or double-hit combination on apoptotic-relevant gene expression in murine lung tissue following 3 cycles of challenge exposure. Murine lung tissues ( $n=3$ /group) were evaluated after 3 cycles of hyperoxia and radiation exposure and evaluated by quantitative real-time PCR analysis for (a) GADD45 $\alpha$; (b) Survivin; and (c) BAX gene expression. Levels of target gene mRNA were normalized to $18 \mathrm{~S}$ ribosomal RNA and values are expressed as the mean fold change from CTL. Data are presented as mean $\pm \mathrm{SEM}$. ${ }^{*} p<0.05$ for each exposure condition as it compares with the unexposed control (CTL) in the same respective time-group; ${ }^{\#} p<0.05$ for significant differences between $\mathrm{O}_{2}$-alone compared to $\mathrm{O}_{2}+\mathrm{IR}$; $§ p<0.05$ for significant differences between IR-alone compared to $\mathrm{O}_{2}+\mathrm{IR}$. 
2.11. Expression of Apoptotic and DNA Damage-Induced Proteins in Lung Epithelial Cells Exposed to Hyperoxia, Radiation, and Double-Hit Combination Challenge

We performed an in vivo experiment in mice to test whether our current findings in C10 lung epithelial cells correlate with the actual response of the lung to the selected stressors $\left(\mathrm{O}_{2}, \mathrm{IR}\right.$, and $\mathrm{O}_{2}+\mathrm{IR}$ ) with respect to apoptosis and cell cycle arrest. For this study, mouse cohorts ( $n=3 /$ group) were exposed to repeated: (a) normoxia; (b) $>95 \% \mathrm{O}_{2}\left(\mathrm{O}_{2}\right)$; (c) $0.25 \mathrm{~Gy}$ single fraction gamma radiation (IR); or (d) a combination of $\mathrm{O}_{2}$ and IR $\left(\mathrm{O}_{2}+\mathrm{IR}\right)$. We decided, in order to ensure that changes are detectable in intact lungs, to expose mice to 3 cycles of the stress conditions, as opposed to the 2 cycles used in the in vitro experiments. Murine lung tissue was then evaluated for the expression of key apoptotic and cell cycle proteins (GADD45 $\alpha$, Survivin, Bax, CDK1, and Cyclin B1) as determined in $\mathrm{C} 10$ epithelial cells. Similarly to our in vitro results in $\mathrm{C} 10$ cells, murine lung (with quiescent respiratory epithelium), exposed to three cycles of hyperoxia ( $8 \mathrm{~h}$ ) and radiation ( $0.25 \mathrm{~Gy}$ total body irradiation) exposure led to significant $(p<0.05)$ reductions in CDK1 $\left(12 \%, 68 \%\right.$, and $72 \%$ decrease for $\mathrm{O}_{2}, \mathrm{IR}$, and $\mathrm{O}_{2}+\mathrm{IR}$, respectively) and cyclin $\mathrm{B} 1\left(35 \%, 69 \%\right.$, and $95 \%$ decrease for $\mathrm{O}_{2}, \mathrm{IR}$, and $\mathrm{O}_{2}+\mathrm{IR}$, respectively) cell cycle protein levels (Figure 11). Importantly, the combined challenge exposure $\left(\mathrm{O}_{2}+\mathrm{IR}\right)$ led to significantly $(p<0.05)$ further reductions in both proteins compared to exposure to hyperoxia-alone. Furthermore, levels of GADD $45 \alpha$ were equally elevated across all challenge conditions (62-, 43-, and 45 -fold increased over CTL exposed mice for $\mathrm{O}_{2}, \mathrm{IR}$, and $\mathrm{O}_{2}+$ IR exposure, respectively).

a

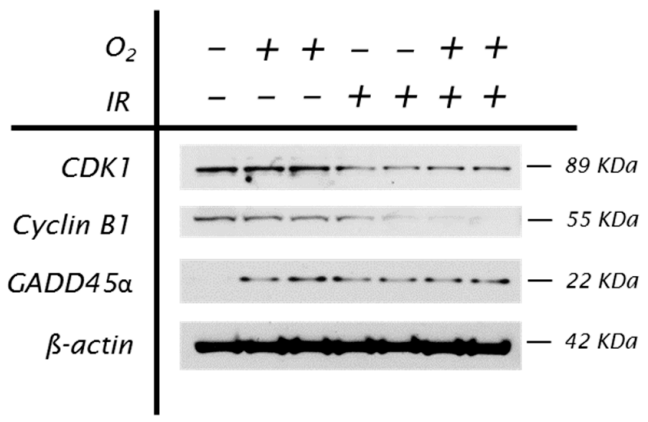

b

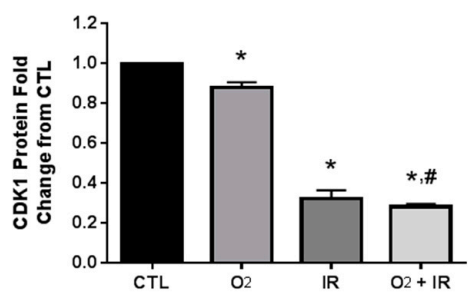

C

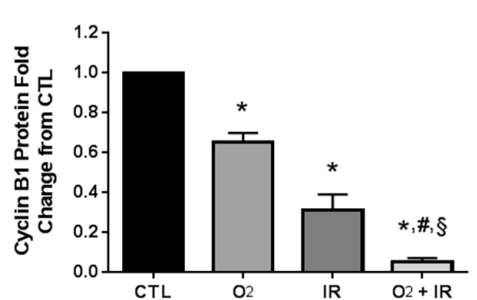

d

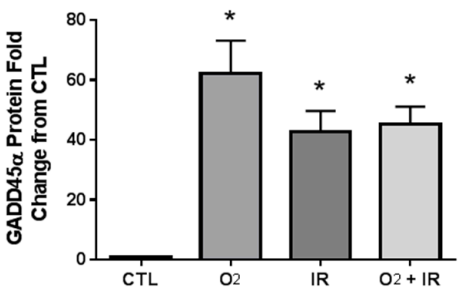

Figure 11. Determination of apoptotic and cell cycle proteins in murine lung tissue following exposure to repeated cycles of $\mathrm{O}_{2}$, IR or $\mathrm{O}_{2}+\mathrm{IR}$ exposure. Murine lung tissues ( $n=3 /$ group) were evaluated after 3 cycles of hyperoxia and radiation exposure and evaluated by (a) western blotting for CDK1, Cyclin B1, and GADD45 $\alpha$. Densitometric analysis of band intensity for (b) CDK1; (c) Cyclin B1; and (d) GADD45 $\alpha$ was normalized to $\beta$-actin and values are expressed as fold change from CTL. Data are presented as mean \pm SEM. ${ }^{*} p<0.05$ for each exposure condition as it compares with the unexposed control (CTL) in the same respective time-group; ${ }^{\#} p<0.05$ for significant differences between $\mathrm{O}_{2}$-alone compared to $\mathrm{O}_{2}+\mathrm{IR} ; \S p<0.05$ for significant differences between IR-alone compared to $\mathrm{O}_{2}+\mathrm{IR}$.

\section{Discussion}

We have recently identified possible pulmonary toxicity associated with space travel by the use of a cell system to model repeated individual or combined stressors such as radiation or high oxygen levels associated with space exploration [12]. Our findings from the current in vitro model system of similar cycling levels of hyperoxia/radiation exposure identified damage at the lung cellular level, showing marked increases in DNA damage and apoptosis, and decreases in cell survival that were 
especially profound in the double-hit combination challenge group. Cells exposed to $\mathrm{O}_{2}$ and IR challenges also displayed increased phosphorylation of H2AX along with elevated levels of DNA damage-induced proteins, cleaved-PARP and GADD $45 \alpha$ proteins, correlating with decreased survivin and increased GADD $45 \alpha$ and $B A X$ gene expression. The significant levels of epithelial cell death following exposure to radiation and hyperoxia detected in this study attributed to increased apoptosis, cell cycle arrest, and increased oxidative stress provides, in part, an explanation for the tissue damage and toxicity observed in the lungs of animals exposed to similar cycling exposures to the same challenges $[12,13]$. The information presented here, in combination with our in vivo findings, provides useful information applicable to ongoing research relevant to human space missions.

Our in vitro model of double-hit exposure revealed that double-hit combination challenge results in increased cell death and apoptosis as compared to either hyperoxia or IR alone. Pulmonary epithelial cells exposed to the double-hit challenge also expressed increased levels of cleaved-PARP, GADD45 $\alpha$ cleaved caspase-3, and BAX. The increase in cleaved-PARP and GADD $45 \alpha$ proteins was observed after exposure to 1 and 2 cycles ( 24 and $48 \mathrm{~h}$ ) of challenge conditions in pulmonary epithelial cells, especially among cells exposed to combination treatment. Increased GADD $45 \alpha$ expression also correlated with increased DNA damage and apoptotic cell death indicating GADD $45 \alpha$ induced activation of caspase-3 through cellular increases in BAX. At the same time, the level of cell cycle arrest protein p21 was elevated, while the levels of CDK1 and cyclin B1 were decreased in cells exposed to $\mathrm{O}_{2}$ and IR. Accumulation of p21 inhibits G2/M transition leading to cell cycle arrest, which was observed after 2 cycles of exposure among cells exposed to hyperoxia and hyperoxia plus radiation [18]. Activation of CDK1-Cyclin B1 complex is necessary for cell cycle G2/M transition. We acknowledge a discrepancy between the findings from the western blot analysis of cell cycle proteins, such as p21 and phospho-p53, and the cell cycle arrest analysis determined by flow cytometry. Specifically, flow cytometry showed that exposure to IR after 24 and $48 \mathrm{~h}$ did not alter cell cycle; however, western blot evaluation showed that upon IR exposure, both p21 and phosphor-p53 were both induced. According to our data, although the dose of radiation exposure ( $0.25 \mathrm{~Gy}$ for 1 cycle and $0.50 \mathrm{~Gy}$ for 2 cycles of exposure) is able to induce an elevation in phospho-p53 and p21, it is not able to induce cell-cycle arrest as determined by DNA content using flow cytometry. The extent of cellular damage following exposure to such low radiation levels ( 0.25 or $0.50 \mathrm{~Gy})$ may not be sufficient to induce cell cycle arrest. However, such exposure may lead to the phosphorylation of cell cycle proteins, which we have indeed identified by western blot analysis.

It is known that p53 holds a regulatory role not only for the G1 phase of the cell cycle, but also for the G2/M phase, which has been reviewed by Taylor and Stark [31]. Thus phospho-p53 and subsequently p21, a downstream activated protein can be used as markers of cell cycle arrest in G2/M phase of the cell cycle as well. These studies warrant additional investigation to further evaluate lung epithelial cell cycle arrest and cellular apoptosis relevant to the double-hit condition and to identify potential countermeasures of this damage as described in a recent review by Schmidt and Goodwin [6]. Indeed, pathological changes in hyperoxic lungs, for example, are associated with lung cell death via apoptosis or necrosis [32-35]. Similarly, IR can directly target critical cellular macromolecules such as DNA, proteins and lipids. DNA damage by radiation that cannot be repaired condemns the cell to reproductive death by either apoptosis, mitotic catastrophe or senescence [36].

Based on the data presented in this in vitro study, as well as in our previous in vivo study of double-hit combined challenge of hyperoxia and radiation, we present the proposed mechanism of hyperoxia plus $\gamma$-irradiation-induced lung cell death (see Figure 12). It is known that hyperoxia and $\gamma$-irradiation produce ROS and reactive nitrogen species (RNS) and results in DNA damage [12]. Our current findings show increased phosphorylation of $\gamma-\mathrm{H} 2 \mathrm{AX}$, indicative of increased DNA damage. The double-hit challenge induces both the apoptotic response as well as the cell cycle arrest response, while exposure to hyperoxia or radiation alone increased the number of necrotic cells. Our results show an increased level of cleaved-PARP in challenged cells. Increased activation of PARP would lead to increased utilization of ATP for poly(ADP-ribosyl)ation reactions to facilitate DNA replication, however, resulting in depletion of cellular ATP that further leads to cell death. We have also observed apoptosis and cell death in our in vitro model confirming that PARP activation may 
contribute to cell death following exposure to hyperoxia and radiation. Simultaneously, increased expression of GADD45 $\alpha$ (a DNA-damage inducible protein) [26-28], as observed in this current study, would lead to dissociation of Bim (an apoptotic protein) from microtubule associated components and translocate to mitochondria. Once in the mitochondria, Bim interacts with Bcl-2 and results in relieving BAX that leads to the release of cytochrome $\mathrm{c}$ from the mitochondria to the cytosolic compartment where it activates procaspase- 9 to active caspase- 9 , the initiator of programmed cell death. Activated caspase- 9 then activates procaspase- 3 to caspase- 3 that acts on the CAD/ICAD complex (Caspase-activated DNase/inhibitor of CAD) to release CAD, which translocates to the nucleus and results in the breaking down of nuclear DNA at specific sites and subsequent cell death. Therefore, increased levels of GADD $45 \alpha$, BAX, and cleaved caspase-3, as seen in our current studies, may signify a novel mechanism by which double-hit radiation/hyperoxia exposure of cells leads to DNA damage and ultimately cell death.

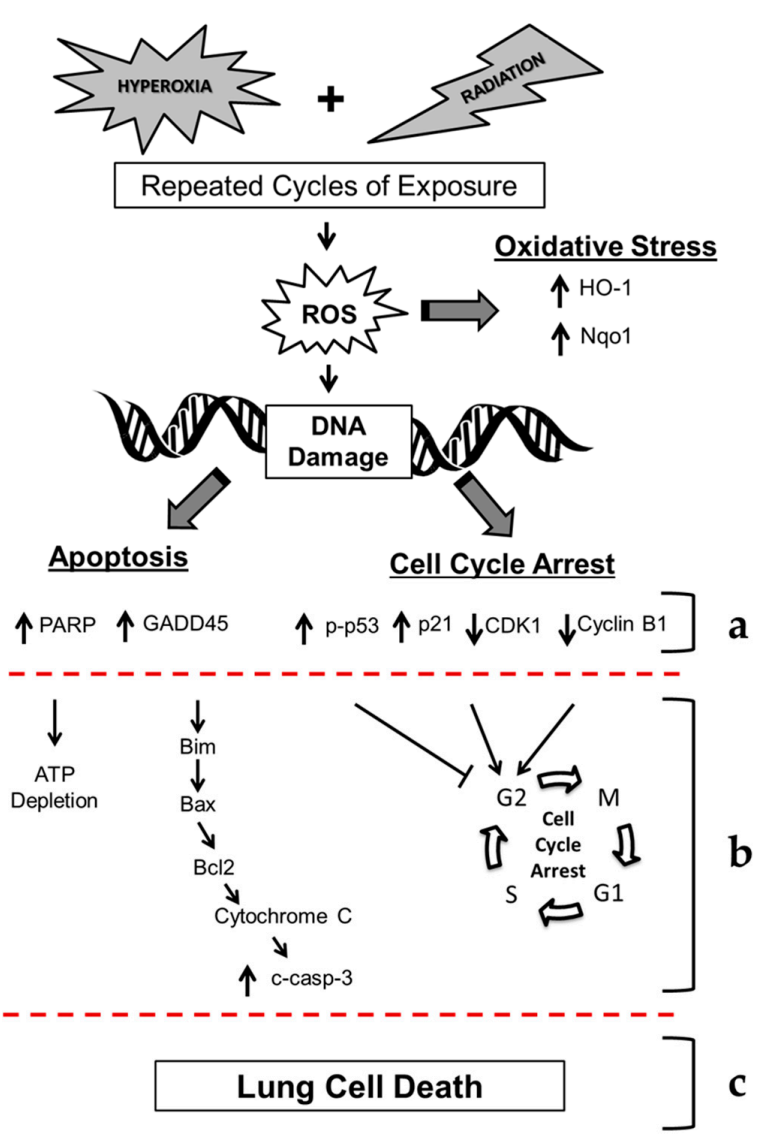

Figure 12. Mechanism of cell death in murine lung epithelial cells after repeated cycles of hyperoxia, radiation, and double-hit combination challenge. Hyperoxia and radiation exposure generates reactive oxygen species (ROS) that lead to increases in DNA damage. Oxidative stress induces the expression of cytoprotective enzymes (HO-1 and Nqo1). We observed significant increases in molecular markers of DNA damage ( $\gamma-\mathrm{H} 2 \mathrm{AX}, \mathrm{GADD} 45 \alpha$ and cleaved-PARP), along with a key upstream executioners of apoptosis (cleaved caspase-3). (a) Additionally, we observed increased Annexin- $\mathrm{V}$, a marker of apoptosis, and levels of apoptotic proteins (cleaved PARP, GADD45 $\alpha$, and cleaved caspase-3) and altered levels of cell signaling proteins (phopso-p53, p21, CDK1 and cyclin B1). Therefore, we propose that hyperoxia and radiation exposure (b) increase apoptosis (via ATP depletion and activation of the intrinsic apoptotic pathway) and G2/M cell cycle arrest, ultimately leading to (c) lung cell death. $\uparrow$ indicates an increase in gene expression or protein levels; $\downarrow$ indicates a decrease in gene expression or protein levels. 
In our current study under the challenge condition, the expression of p21 protein increased while the expression CDK1 and Cyclin B1 proteins decreased. The increase in the cell cycle signaling protein p21 following exposure to hyperoxia and radiation led to cell cycle transition arrest at G2/M. It is well known that p21 is an inhibitor of the CDK1-Cyclin B1 complex [18]. We have observed increased expression of p21 and decreased expression of CDK1 and Cyclin B1 following exposure to hyperoxia and radiation. Therefore, such an increase in p21 and a simultaneous decrease in CDK1 and cyclin $B$ would result in cell cycle arrest and cell death. In our current study, we have observed increased apoptosis, DNA damage, and oxidative stress following exposure to hyperoxia and radiation challenge conditions, which may be a potential mechanism of EVA-relevant cell damage leading to cell death (see Figure 12). We acknowledge that several other factors may contribute to cell death observed in the double-hit combination challenge as described extensively by Cucinotta and co-workers [37-39]. Specifically it would be important to investigate DNA repair mechanisms and how they relate to the observed cell damage and death seen in our in vitro model system.

Additionally, we acknowledge the use of proliferating C10 murine pulmonary type II epithelial cells, which were undergoing proliferation during experimentation, despite the quiescent state of the respiratory epithelium as a potential limitation of the current study findings. Furthermore, while the current findings represent only a cell model of investigating the consequences of radiation and hyperoxia to the whole lung, the importance of specifically investigating the lung epithelium and molecular mechanisms underlying such exposures is warranted. Exposure to sublethal levels of high oxygen causes damage to all cell structures of the alveolus including damage to nearly $50 \%$ of the lung capillary endothelial cells [15]. For this reason, in our recent work by Velalopoulou et al. [40] we evaluated radiation exposures in other relevant lung cell types. However, exposure to hyperoxia are initially detected by the epithelial lining of the airways, which prompted us to use this cell type to evaluate relevant pathways that might be involved. It is, however, known by the work of many investigators, that endothelial and interstitial cells are also affected by high oxygen levels [41]. In fact, work in rats and baboons exposed to high oxygen $(40 \%-60 \%)$, showed an increase in interstitial cells, quantitative evidence of injury to alveolar epithelial cells, and a significant fall in the number of capillary endothelial cells during the late phases of hyperoxic lung injury.

The current Design Reference Missions (DRMs) for planetary exploration detailed by NASA include repeated cyclic exposures to hypobaric mild hypoxia at $8.2 \mathrm{psia} / 34 \% \mathrm{O}_{2}(\sim 4500 \mathrm{ft}$. elevation) for $18 \mathrm{~h}$ mixed with exposure to hypobaric hyperoxia at $4.3 \mathrm{psia} / 100 \% \mathrm{O}_{2}$ for $\sim 6 \mathrm{~h}$ (suit) [6]. This regime will be repeated daily over a two to three week period during exploration DRMs and these conditions have not been characterized in any animal model or in humans. While the current model system outlined above is robust, utilitarian and capable, it lacks two essential requirements to adequately test the DRMs defined by the National Aeronautics and Space Administration (NASA). First the ability to simulate microgravity and second the longevity to be maintained over weeks and even months. Thus, in the future we plan to pursue experimentation in a 3 dimensional (3D) model of human lung developed by our colleagues at the NASA Johnson Space Center. This complex model of human lung propagated in $3 \mathrm{D}$ is well characterized $[42,43]$ and presents with the typical biomarkers expected of normal human lung during prolonged culture ( $>3$ months). Additionally the model is developed in a modeled microgravity environment reflective of conditions seen in actual space habitation. This system is easily manipulated to test potential countermeasures to the combined effects of cyclic hypobaric $\mathrm{O}_{2}$ concentrations (both hypoxic and hyperoxic), microgravity, and various IR exposures. Further, as the system embodies considerable longevity, repeated IR doses may be employed to observe damage and implement protective strategies by dose-dependent countermeasure application. 


\section{Materials and Methods}

\subsection{Experimental Plan of in Vitro Cell Exposure}

Non-tumorigenic murine alveolar type II epithelial cells (C10), a kind gift of Alvin Malkinson, University of Colorado School of Pharmacy [44] were used as surrogates for alveolar epithelial cell injury, as we have previously reported [40]. C10 murine alveolar epithelial Type II cells were grown in 4 mL of Dulbecco's modified Eagle's medium (4500 mg/L glucose; Invitrogen, Carlsbad, CA, USA) containing 10\% fetal bovine serum (Atlanta Biologicals, Norcross, GA, USA), penicillin (100 units / mL), streptomycin (100 mg/mL), and L-Glutamine (2 mM) (Life Technologies, Inc., Gaithersburg, MD, USA). Cells were exposed to: (a) normoxia (CTL); (b) >95\% $\mathrm{O}_{2}\left(\mathrm{O}_{2}\right)$; (c) 0.25 Gy ionizing $\gamma$-radiation (IR); or $(\mathrm{d})$ a combination of $>95 \% \mathrm{O}_{2}$ and $0.25 \mathrm{~Gy}$ ionizing $\gamma$-radiation $\left(\mathrm{O}_{2}+\mathrm{IR}\right)$. These conditions were similar to our in vivo murine model of double-hit exposure to hyperoxia and radiation [12]. Cells were exposed to hyperoxic conditions for $8 \mathrm{~h}$ followed by normoxia (ambient air containing $5 \% \mathrm{CO}_{2}$ ) for $16 \mathrm{~h}$ representing 1 cycle of exposure. Cells were harvested after 1 cycle $(24 \mathrm{~h})$ and 2 cycles (48 h) of exposure.

\subsection{Exposure of Lung Epithelial Cells to Radiation}

Non-tumorigenic murine alveolar type II epithelial cells (C10) were irradiated with a Shepherd Mark $1{ }^{137} \mathrm{Cs}$ irradiator delivering a dose of $1.0 \mathrm{~Gy} / \mathrm{minute}$. Cells were plated in coated $6 \mathrm{~cm}$ Petri dishes (Nalgene-Nunc, Thermo-Fisher, Rochester, NY, USA) to 80\% confluency, placed in aluminum chambers, and sealed under a controlled atmosphere (described below). These chambers allow full exposure of cells to gamma rays. The scheme displayed in Figure 1a shows details of the in vitro procedure.

\subsection{Exposure of Lung Epithelial Cells to Hyperoxia}

Non-tumorigenic murine alveolar type II epithelial cells (C10) [45] were plated in sterile, vented Permanox ${ }^{\mathrm{TM}}$ solvent-resistant plastic $60 \mathrm{~mm} \times 15 \mathrm{~mm}$ cell culture dishes (Permanox, Nunc International, Rochester, NY, USA) and enclosed in specially-designed O-ring sealed, leak-proof aluminum chambers (see Figure 1b) [46]. The atmosphere inside the chambers can be changed to any desired oxygen content through a system of valves and an exposure manifold, as described [46]. Chambers were kept at $37^{\circ} \mathrm{C}$ at all times. Duration of exposure to hyperoxic conditions was for 8 $\mathrm{h}$ followed by normoxia (ambient air containing 21\% $\mathrm{O}_{2}$ and 5\% $\mathrm{CO}_{2}$ ) for $16 \mathrm{~h}$ representing 1 cycle of exposure. Cells were harvested after 1 cycle $(24 \mathrm{~h})$ and 2 cycles $(48 \mathrm{~h})$ of exposure. Work by Allen et al. [47], noted that while it takes just minutes for the air inside a petri dish to equilibrate with the air above it, it takes a few $\mathrm{h}$ for the oxygen content in the medium in the tissue culture flasks and around it to achieve equilibrium. We incubated our cells under hyperoxic conditions for $8 \mathrm{~h}$, which ensured adequate oxygen solubility in the medium. We did not detect any color changes in the medium with oxygen exposure, a sign of $\mathrm{pH}$ change. We therefore, assumed that no modification of the medium was in effect.

\subsection{Western Blotting}

Immunoblot analysis on lung epithelial cell lysates was performed as previously described [48] using primary antibodies against cleaved-poly (ADP-ribose) polymerase (PARP), growth arrest and DNA damage protein (GADD45 $\alpha$ ), phospho-53, p21, cyclin-dependent kinase 1 (CDK1), Cyclin B1, cleaved caspase-3, Bcl-2-associated X protein (BAX), heme oxygenase-1 (HO-1), and NADPH: quinone oxidoreductase-1 (Nqo1) (Cell Signaling Technology, Danvers, MA, USA). Densitometric analysis of western blots with $\beta$-actin normalization of protein expression was performed using Gel-Pro Analyzer software (Version 6.0, MediaCybernetics, Silver Spring, MD, USA). Briefly, cells were lysed in phosphate buffered saline (PBS) containing protease inhibitors. Immunoblot analysis of cell lysates was then performed using 12 well SDS 12\% NuPAGE gel (Invitrogen, Carlsbad, CA, 
USA). Electrophoresis was performed at 200 volts for $1 \mathrm{~h}$. Transfer to PolyScreen PVDF transfer membrane (PerkinElmer Life Sciences, Boston, MA, USA) was performed for $1 \mathrm{~h}$ at 25 volts at room temperature. Membrane was blocked overnight in 5\% non-fat dry milk in PBS. The non-fat dry milk was then discarded and the membrane was incubated with primary antibody. Protein levels of cleaved-PARP, GADD45 $\alpha$, phospho-p53, p21, CDK1, cyclin B1, cleaved caspase-3, BAX, HO-1, and Nqo1 were detected using manufacturer recommended dilutions (Cell Signaling Technology, Danvers, MA, USA). The membrane was washed five times and then incubated in secondary antibody conjugated to horseradish peroxidase for $45 \mathrm{~min}$ at room temperature. Membranes were developed using Western Lighting Chemiluminescence Reagent Plus (PerkinElmer Life Sciences, Boston, MA, USA) and quantified by densitometric analysis of specific bands ( $89 \mathrm{kDa}$ for cleaved-PARP, $22 \mathrm{kDa}$ for GADD45 $\alpha, 53 \mathrm{kDa}$ for phospho-p53, $21 \mathrm{kDa}$ for p21, $34 \mathrm{kDa}$ for CDK1, $55 \mathrm{kDa}$ for cyclin B1, 17/19 kDa for cleaved caspase-3, $20 \mathrm{kDa}$ for BAX, $28 \mathrm{kDa}$ for HO-1, and $29 \mathrm{kDa}$ for Nqo1) that were adjusted for loading using $\beta$-actin expression levels.

\subsection{Lung Epithelial Cell Counts}

Cell counting was performed using an inverted Olympus IX-51-microscope fitted with a BASLER scA1300-32fm monochrome digital camera. This setup was connected to a PC equipped with Image J software (National Institutes of Health, Bethesda, MD, USA; Available online: http://imagej.nih.gov/ij/; 1997-2016). Treated cells growing in $6 \mathrm{~cm}$ Petri dishes were stained with Crystal Violet (Sigma, St. Louis, MO, USA). Dishes were mounted onto the microscope stage equipped with a special holder and photographed. Images were captured from 5 randomly-selected fields per dish at $200 \times$ magnification. Captured images were processed using the cell counting function of Image J.

\subsection{Comet Analysis}

Non-tumorigenic murine alveolar type II epithelial cells (C10) were challenged with hyperoxia and/or radiation and processed for comet assay analysis as per manufacturer's instructions (Trevigen, Gaithersburg, MD, USA). Briefly, cells $\left(1 \times 10^{5}\right.$ cells $/ \mathrm{mL}$ in PBS) were mixed with LMAgarose ${ }^{\circledR}(1: 10$, $v / v)$ and immediately pipetted onto Trevigen's CometSlides ${ }^{\mathrm{TM}}$. Cells were then lysed $\left(4{ }^{\circ} \mathrm{C}, 30 \mathrm{~min}\right)$ and kept in dark for unwinding at room temperature. Electrophoresis was done in a horizontal electrophoresis unit at 18 volts $(300 \mathrm{~mA})$ for $25 \mathrm{~min}$. Slides were washed twice with deionized water, fixed in $70 \%$ ethanol and dried at $45{ }^{\circ} \mathrm{C}$. DNA was stained by SYBR green (Trevigen). At least 150 cells were scored per group. Visual analysis of cells and comet tail length was measured using Comet Image Analysis software (Comet Assay IV, Perceptive Instruments Ltd., Haverhill, UK). Images were captured on an Olympus IX51 fluorescence microscope using a monochrome CCD FireWire camera (Perceptive Instruments Ltd., Haverhill, UK).

\subsection{Gene Expression Analysis}

Quantitative Polymerase Chain Reaction (qPCR) was performed using TaqMan ${ }^{\circledR}$ Probe-Based Gene Expression Assays supplied by Applied Biosystems, Life Technologies (Carlsbad, CA, USA). Individual TaqMan gene expression assays were selected for GADD45 $\alpha$, Survivin (Birc5: baculoviral inhibitor of apoptosis repeat-containing 5), and Bcl-2-associated X protein (BAX). Briefly, cells were lysed and RNA was isolated using a commercially available kit, QIAprep Spin Miniprep Kit, supplied by Qiagen (Valencia, CA, USA). Total RNA was quantified using a NanoDrop 2000 (ThermoFisher Scientific, Waltham, MA, USA). Reverse transcription of RNA to cDNA was then performed on a Veriti ${ }^{\circledR}$ Thermal Cycler using the High Capacity RNA to cDNA kit supplied by Applied Biosystems, Life Technologies (Carlsbad, CA, USA). Quantitative real-time PCR was performed using $50 \mathrm{ng}$ of cDNA per reaction well on a StepOnePlus ${ }^{\mathrm{TM}}$ Real-Time PCR System (Applied Biosystems, Life Technologies, Carlsbad, CA, USA). Gene expression data was normalized to $18 \mathrm{~S}$ ribosomal RNA housekeeping gene and calibrated to the control samples according to the $2^{-\Delta \Delta \mathrm{Ct}}$ method as previously described $[40,49,50]$. 


\subsection{Analysis of Cell Cycle by Flow Cytometry}

Non-tumorigenic murine alveolar type II epithelial cells (C10) exposed to CTL, $\mathrm{O}_{2}$, IR, or $\mathrm{O}_{2}+\mathrm{IR}$ were trypsinized, washed with 1\% FBS in PBS, resuspended in PBS, and fixed in ice-cold ethanol. After fixation, cells were washed with 1\% FBS in PBS, resuspended in PBS, treated with phosphate citric acid buffer (192 mM Na2HPO4; $4 \mathrm{mM}$ citric acid, $\mathrm{pH}$ 7.8), and stained in PI/RNase buffer (50 $\mu \mathrm{g} / \mathrm{mL}$ propidium iodide, $267 \mu \mathrm{g} / \mathrm{mL}$ RNase A, $1 \%$ FBS in PBS). A FACSCalibur flow cytometer (BD Biosciences, San Jose, CA, USA) was used to measure the DNA content of 20,000 cells per sample. Cell cycle analysis was performed with FlowJo V10.1 software (Ashland, OR, USA).

\subsection{Analysis of Apoptosis/Necrosis by Flow Cytometry}

For the evaluation of apoptotic and necrotic death by flow cytometry, cells were exposed to 2 cycles $(48 \mathrm{~h})$ of hyperoxia, and/or radiation and harvested following trypsinization and centrifugation, at $1500 \mathrm{rpm}$, for $5 \mathrm{~min}$, at $4{ }^{\circ} \mathrm{C}$. Cells were stained by using Abcam's Annexin V-FITC Apoptosis Detection Kit (ab14085, Abcam, Cambridge, MA, USA) according to the manufacturer's instructions. Briefly, cells were incubated with $500 \mu \mathrm{L}$ of $1 \times$ Binding Buffer, $5 \mu \mathrm{L}$ Annexin V-FITC and $5 \mu \mathrm{L}$ propidium iodide (PI) for $10 \mathrm{~min}$ in the dark, at room temperature. Samples were analyzed in a FACSCanto system (BD Biosciences, San Jose, CA, USA) and the data were processed using FlowJo V10.1 software.

\subsection{Analysis of H2AX Phosphorylation by Flow Cytometry}

For the cytometric analysis of H2AX phosphorylation (on serine 139), cells exposed to 2 cycles $(48 \mathrm{~h})$ of hyperoxia, and/or radiation and harvested in DMEM, and washed in cold PBS twice, at $1500 \mathrm{rpm}$, at $4{ }^{\circ} \mathrm{C}$, for $5 \mathrm{~min}$. Cell pellet was resuspended in ice cold solution of $70 \%$ ethanol and the samples were incubated at $-20^{\circ} \mathrm{C}$ for $1 \mathrm{~h}$. Cells were washed twice in cold FACS buffer $(10 \% \mathrm{FBS}, 0.1 \%$ NaN3 in PBS) and collected by centrifugation. H2AX phosphorylation was evaluated by incubating C10 cells with Alexa Fluor ${ }^{\circledR} 647$ anti-H2A.X-Phosphorylated (Ser139) Antibody (Biolegend, San Diego, CA, USA), overnight at $4{ }^{\circ} \mathrm{C}$ following the manufacturer's instructions for the appropriate dilution, in FACS buffer. Next day, cells were washed three times in cold FACS buffer and the cells were resuspended at $0.5 \times 10^{7}-1 \times 10^{7}$ cells $/ \mathrm{mL}$ of FACS buffer. Samples were kept on ice and protected from light until analysis in a FACSCanto system (BD Biosciences, San Jose, CA, USA). Data were analyzed using FlowJo V10.1 software.

\subsection{In Vivo Animal Exposure Study Design}

Our studies used female C57 / BL6 mice exposed to radiation, hyperoxia, or combination challenge, as previously described [12,13]. Mice were obtained from Charles River (Wilmington, MA, USA) and irradiated at 6-8 weeks of age under animal protocols approved by the Institutional Animal Care and Use Committee (IACUC) of the University of Pennsylvania. Animals were housed in conventional cages under standardized conditions with controlled temperature and humidity and a 12-12 h day-night light cycle. Animals had free access to water and chow (Semipurified AIN-93G diet, Test Diet, Bloomsburg, IN, USA). For this study mouse cohorts ( $n=3$ /group) were exposed to: (a) normoxia; (b) $>95 \% \mathrm{O}_{2}\left(\mathrm{O}_{2}\right)$; (c) 0.25 Gy ionizing gamma radiation (IR); or (d) a combination of $>95 \% \mathrm{O}_{2}$ and $0.25 \mathrm{~Gy}$ ionizing gamma radiation $\left(\mathrm{O}_{2}+\mathrm{IR}\right)$. Mice were exposed to 3 cycles of challenge conditions and euthanized for lung tissue evaluation.

Mouse irradiation was performed with a Gammacell 40 137Cs irradiator (Atomic Energy of Canada Limited, Ottawa, ON, Canada) as described in our previous work [12,13]. During irradiation, the animals were held in a circular, well-ventilated custom-made Plexiglas container that minimized their movement so that the whole body would uniformly receive the radiation dose. Mice exposed to 0 Gy served as sham controls. The average dose rate was $0.43 \mathrm{~Gy}$ per minute and was corrected for decay each day. The delivered dose was 0.25 Gy given 3 times a week (Monday, Wednesday, and Friday). Mice were immediately placed in hyperoxic conditions for $8 \mathrm{~h}$ following irradiation. 
Mice were exposed to a continuous flow of $\mathrm{pO}_{2}$ at $10 \mathrm{~L} / \mathrm{min}$ in micro-isolator cages after removing the lids and placing the cages in a sealed Plexiglas chamber that allowed the simultaneous exposure of 6 mouse cages, yielding $\mathrm{O}_{2}$ concentrations of $95 \%-100 \%$ for $8 \mathrm{~h}$ followed by intervening normoxia (ambient air containing $21 \% \mathrm{O}_{2}$ and $5 \% \mathrm{CO}_{2}$ ).

\subsection{Statistical Analysis}

All data were analyzed using two-way analysis of variance (ANOVA) to test for the main effects of time and challenge $\left(\mathrm{O}_{2}, \mathrm{IR}\right.$, and $\left.\mathrm{O}_{2}+\mathrm{IR}\right)$ exposure on measured parameters. Post-tests (Tukey's multiple comparisons tests) were conducted analyzing significant differences among treatment groups (CTL, $\mathrm{O}_{2}, \mathrm{IR}$, and $\mathrm{O}_{2}+\mathrm{IR}$ ) within each harvest time point (24- and $48 \mathrm{~h}$ ). Statistically significant differences were determined using GraphPad Prism version 6.00 for Windows, GraphPad Software (La Jolla, CA, USA; Available online: www.graphpad.com). Results are reported as mean \pm the standard error of the mean (SEM). Levels of target gene mRNA are reported as the mean fold change from CTL at each of the respective time points ( 24 and $48 \mathrm{~h}) \pm$ SEM. Statistically significant differences were determined at $p$-value of 0.05 . Asterisks shown in figures indicate significant differences between exposure groups $\left(\mathrm{O}_{2}, \mathrm{IR}\right.$, and $\left.\mathrm{O}_{2}+\mathrm{IR}\right)$ and unexposed non-tumorigenic murine alveolar type II epithelial cells (CTL). \# shown in figures indicate significant differences between $\mathrm{O}_{2}$-alone compared to $\mathrm{O}_{2}+\mathrm{IR} . \S^{\S}$ shown in figures indicate significant differences between IR-alone compared to $\mathrm{O}_{2}+\mathrm{IR}$.

\section{Conclusions}

The current study aimed to provide novel evidence relevant to cell damage associated with lung complications from space exploration by developing a novel cell model system of combined stressors such as radiation and high oxygen levels. We have characterized a novel in vitro model system to study the effects of repeated double-hit exposure to low-level radiation and hyperoxia in lung epithelial cells. We have identified mechanisms of cell damage leading to cell death such as activation of apoptotic pathways, induction of cell cycle arrest, and a notable increase in oxidative stress that would be useful for identifying risks and testing potential countermeasure strategies for mitigating lung injury associated with prolonged space travel.

Acknowledgments: We would like to thank Ruth Globus for the helpful comments and suggestions. We would also like to thank Sonia Tyagi for her help in the comet analysis and quantification of apoptosis. This work was funded in part by: the National Aeronautics and Space Administration (NASA) Human Research Program through a NASA-National Institutes of Health (NIH) Interagency Agreement for supplemental award to NIH and by NASA award \#NNX12AK19G (Melpo Christofidou-Solomidou), NIH-R01 CA133470 (Melpo Christofidou-Solomidou), NIH-1R21AT008291-01 (Melpo Christofidou-Solomidou), NIH-R03 CA180548 (Melpo Christofidou-Solomidou), 1P42ES023720-01 (Melpo Christofidou-Solomidou) and by pilot project support from 1P30 ES013508-02 awarded to Melpo Christofidou-Solomidou (its contents are solely the responsibility of the authors and do not necessarily represent the official views of the NIEHS, NIH).

Author Contributions: Ralph A. Pietrofesa performed biochemical assays, conducted data analysis and interpretation, and assisted with manuscript preparation. Anastasia Velalopoulou conducted data analysis and interpretation, and contributed to writing the manuscript. Stacey L. Lehman performed flow cytometry and cell cycle analysis and assisted with manuscript preparation. Evguenia Arguiri assisted with the cell culture experiments. Pantelis Solomides performed all cell counts and cell survival evaluations. Cameron J. Koch designed the exposure chambers, provided support in radiation dosimetry, and assisted with manuscript preparation. Om P. Mishra assisted with interpretation of data and manuscript preparation. Constantinos Koumenis assisted with data analysis and manuscript preparation. Thomas J. Goodwin assisted with interpretation of data and manuscript preparation. Melpo Christofidou-Solomidou designed the study and individual experiments, analyzed data, wrote the manuscript and supervised lab personnel. All co-authors reviewed the manuscript before submission and approved the final version.

Conflicts of Interest: Melpo Christofidou-Solomidou reports grants from the NIH during the conduct of the study. In addition, Melpo Christofidou-Solomidou has patents No. PCT/US14/41636 and No. PCT/US15/22501 pending and has a founders equity position in LignaMed, limited liability company (LLC). All other coauthors report no actual, potential, or perceived conflict of interest with regard to this manuscript. 


\section{Abbreviations}

$\begin{array}{ll}\text { BAX } & \text { Bcl-2-associated X protein } \\ \text { Casp-3 } & \text { caspase-3 } \\ \text { Casp-9 } & \text { caspase-9 } \\ \text { CDK1 } & \text { Cyclin-dependent kinase 1 } \\ \text { CTL } & \text { control } \\ \text { DCI } & \text { decompression Illness } \\ \text { EVA } & \text { extravehicular activity } \\ \text { GADD45 } \alpha & \text { growth arrest and DNA damage } \\ \text { HO-1 } & \text { heme oxygenase-1 } \\ \text { IAP } & \text { inhibitor of apoptosis } \\ \text { Nqo1 } & \text { NADPH: quinone oxidoreductase-1 } \\ \text { PARP } & \text { poly(ADP-ribose) polymerase } \\ \text { PBS } & \text { phosphate buffered saline } \\ \text { qPCR } & \text { quantitative polymerase chain reaction } \\ \text { RNS } & \text { reactive nitrogen species } \\ \text { ROS } & \text { reactive oxygen species } \\ \text { SEM } & \text { standard error of mean }\end{array}$

\section{References}

1. Hu, S.; Kim, M.H.; McClellan, G.E.; Cucinotta, F.A. Modeling the acute health effects of astronauts from exposure to large solar particle events. Health Phys. 2009, 96, 465-476. [CrossRef] [PubMed]

2. Townsend, L.W. Implications of the space radiation environment for human exploration in deep space. Radiat. Prot. Dosim. 2005, 115, 44-50. [CrossRef] [PubMed]

3. Holloway, R.J.; Leong, G.F.; Ainsworth, E.J.; Albright, M.L.; Baum, S.J. Recovery from radiation injury in the hamster as evaluated by the split-dose technique. Usnrdl-tr-1111. Res. Dev. Tech. Rep. 1967, 1-26.

4. Leong, G.F.; Page, N.P.; Ainsworth, E.J.; Hanks, G.E. Injury accumulation in sheep during protracted gamma radiation. Usnrdl-tr-998. Res. Dev. Tech. Rep. 1966, 1-13.

5. Prisk, G.K. The lung in space. Clin. Chest Med. 2005, 26, 415-438. [CrossRef] [PubMed]

6. Schmidt, M.A.; Goodwin, T.J. Personalized medicine in human space flight: Using omics based analyses to develop individualized countermeasures that enhance astronaut safety and performance. Metabolomics 2013, 9, 1134-1156. [CrossRef] [PubMed]

7. Larkin, E.C.; Adams, J.D.; Williams, W.T.; Duncan, D.M. Hematologic responses to hypobaric hyperoxia. Am. J. Physiol. 1972, 223, 431-437. [PubMed]

8. Madden, L.A.; Chrismas, B.C.; Mellor, D.; Vince, R.V.; Midgley, A.W.; McNaughton, L.R.; Atkin, S.L.; Laden, G. Endothelial function and stress response after simulated dives to $18 \mathrm{msw}$ breathing air or oxygen. Aviat. Space Environ. Med. 2010, 81, 41-45. [CrossRef] [PubMed]

9. Hellweg, C.E.; Baumstark-Khan, C. Getting ready for the manned mission to mars: The astronauts' risk from space radiation. Naturwissenschaften 2007, 94, 517-526. [CrossRef] [PubMed]

10. Cucinotta, F.A.; Kim, M.H.; Willingham, V.; George, K.A. Physical and biological organ dosimetry analysis for international space station astronauts. Radiat. Res. 2008, 170, 127-138. [CrossRef] [PubMed]

11. Christofidou-Solomidou, M.; Pietrofesa, R.A.; Arguiri, E.; Schweitzer, K.S.; Berdyshev, E.V.; McCarthy, M.; Corbitt, A.; Alwood, J.S.; Yu, Y.; Globus, R.K.; et al. Space radiation-associated lung injury in a murine model. Am. J. Physiol. Lung Cell. Mol. Physiol. 2015, 308, L416-L428. [CrossRef] [PubMed]

12. Pietrofesa, R.A.; Turowski, J.B.; Arguiri, E.; Milovanova, T.N.; Solomides, C.C.; Thom, S.R.; Christofidou-Solomidou, M. Oxidative lung damage resulting from repeated exposure to radiation and hyperoxia associated with space exploration. J. Pulm. Respir. Med. 2013, 3, 1000158. [PubMed]

13. Pietrofesa, R.A.; Solomides, C.C.; Christofidou-Solomidou, M. Flaxseed mitigates acute oxidative lung damage in a mouse model of repeated radiation and hyperoxia exposure associated with space exploration. J. Pulm. Respir. Med. 2014, 4, 1000215. [CrossRef] [PubMed]

14. Movsas, B.; Raffin, T.A.; Epstein, A.H.; Link, C.J., Jr. Pulmonary radiation injury. Chest 1997, 111, $1061-1076$. [CrossRef] [PubMed]

15. Crapo, J.D.; Barry, B.E.; Chang, L.Y.; Mercer, R.R. Alterations in lung structure caused by inhalation of oxidants. J. Toxicol. Environ. Health 1984, 13, 301-321. [CrossRef] [PubMed] 
16. Perkowski, S.; Scherpereel, A.; Murciano, J.C.; Arguiri, E.; Solomides, C.C.; Albelda, S.M.; Muzykantov, V.; Christofidou-Solomidou, M. Dissociation between alveolar transmigration of neutrophils and lung injury in hyperoxia. Am. J. Physiol. Lung Cell. Mol. Physiol. 2006, 291, L1050-L1058. [CrossRef] [PubMed]

17. Machtay, M.; Scherpereel, A.; Santiago, J.; Lee, J.; McDonough, J.; Kinniry, P.; Arguiri, E.; Shuvaev, V.V.; Sun, J.; Cengel, K.; et al. Systemic polyethylene glycol-modified (pegylated) superoxide dismutase and catalase mixture attenuates radiation pulmonary fibrosis in the c57/b16 mouse. Radiother. Oncol. 2006, 81, 196-205. [CrossRef] [PubMed]

18. Taieb, F.; Nougayrede, J.P.; Oswald, E. Cycle inhibiting factors (cifs): Cyclomodulins that usurp the ubiquitin-dependent degradation pathway of host cells. Toxins (Basel) 2011, 3, 356-368. [CrossRef] [PubMed]

19. Al-Khalaf, H.H.; Mohideen, P.; Nallar, S.C.; Kalvakolanu, D.V.; Aboussekhra, A. The cyclin-dependent kinase inhibitor p16ink4a physically interacts with transcription factor sp1 and cyclin-dependent kinase 4 to transactivate microrna-141 and microrna-146b-5p spontaneously and in response to ultraviolet light-induced DNA damage. J. Biol. Chem. 2013, 288, 35511-35525. [CrossRef] [PubMed]

20. Pietenpol, J.A.; Stewart, Z.A. Cell cycle checkpoint signaling: Cell cycle arrest versus apoptosis. Toxicology 2002, 181-182, 475-481. [CrossRef]

21. Alenzi, F.Q. Links between apoptosis, proliferation and the cell cycle. Br. J. Biomed. Sci. 2004, 61, 99-102. [CrossRef] [PubMed]

22. Zhang, F.; Zhang, T.; Teng, Z.H.; Zhang, R.; Wang, J.B.; Mei, Q.B. Sensitization to $\gamma$-irradiation-induced cell cycle arrest and apoptosis by the histone deacetylase inhibitor trichostatin a in non-small cell lung cancer (NSCLC) cells. Cancer Biol. Ther. 2009, 8, 823-831. [CrossRef] [PubMed]

23. Valerie, K.; Yacoub, A.; Hagan, M.P.; Curiel, D.T.; Fisher, P.B.; Grant, S.; Dent, P. Radiation-induced cell signaling: Inside-out and outside-in. Mol. Cancer Ther. 2007, 6, 789-801. [CrossRef] [PubMed]

24. Jenkins, R.D.; Sinclair, I.N.; Anand, R.; Kalil, A.G., Jr.; Schoen, F.J.; Spears, J.R. Laser balloon angioplasty: Effect of tissue temperature on weld strength of human postmortem intima-media separations. Lasers Surg. Med. 1988, 8, 30-39. [CrossRef] [PubMed]

25. Poole, P.S.; Sinclair, D.R.; Armitage, J.P. Real time computer tracking of free-swimming and tethered rotating cells. Anal. Biochem. 1988, 175, 52-58. [CrossRef]

26. Tong, T.; Ji, J.; Jin, S.; Li, X.; Fan, W.; Song, Y.; Wang, M.; Liu, Z.; Wu, M.; Zhan, Q. GADD45 $\alpha$ expression induces bim dissociation from the cytoskeleton and translocation to mitochondria. Mol. Cell. Biol. 2005, 25, 4488-4500. [CrossRef] [PubMed]

27. Carrier, F.; Smith, M.L.; Bae, I.; Kilpatrick, K.E.; Lansing, T.J.; Chen, C.Y.; Engelstein, M.; Friend, S.H.; Henner, W.D.; Gilmer, T.M.; et al. Characterization of human GADD45, a p53-regulated protein. J. Biol. Chem. 1994, 269, 32672-32677. [PubMed]

28. Fornace, A.J., Jr.; Alamo, I., Jr.; Hollander, M.C. DNA damage-inducible transcripts in mammalian cells. Proc. Natl. Acad. Sci. USA 1988, 85, 8800-8804. [CrossRef] [PubMed]

29. Gobeil, S.; Boucher, C.C.; Nadeau, D.; Poirier, G.G. Characterization of the necrotic cleavage of poly(ADP-ribose) polymerase (PARP-1): Implication of lysosomal proteases. Cell Death Differ. 2001, 8, 588-594. [CrossRef] [PubMed]

30. Zeng, J.; Yang, G.Y.; Ying, W.; Kelly, M.; Hirai, K.; James, T.L.; Swanson, R.A.; Litt, L. Pyruvate improves recovery after PARP-1-associated energy failure induced by oxidative stress in neonatal rat cerebrocortical slices. J. Cereb. Blood Flow Metab. 2007, 27, 304-315. [CrossRef] [PubMed]

31. Taylor, W.R.; Stark, G.R. Regulation of the G2/M transition by p53. Oncogene 2001, 20, 1803-1815. [CrossRef] [PubMed]

32. Petrache, I.; Choi, M.E.; Otterbein, L.E.; Chin, B.Y.; Mantell, L.L.; Horowitz, S.; Choi, A.M. Mitogen-activated protein kinase pathway mediates hyperoxia-induced apoptosis in cultured macrophage cells. Am. J. Physiol. 1999, 277, L589-L595. [PubMed]

33. Lee, H.S.; Kim, C.K. Effect of recombinant IL-10 on cultured fetal rat alveolar type II cells exposed to 65\%-hyperoxia. Respir. Res. 2011, 12, 68. [CrossRef] [PubMed]

34. Barazzone, C.; Horowitz, S.; Donati, Y.R.; Rodriguez, I.; Piguet, P.F. Oxygen toxicity in mouse lung: Pathways to cell death. Am. J. Respir. Cell Mol. Biol. 1998, 19, 573-581. [CrossRef] [PubMed]

35. Mantell, L.L.; Lee, P.J. Signal transduction pathways in hyperoxia-induced lung cell death. Mol. Genet. Metabol. 2000, 71, 359-370. [CrossRef] [PubMed] 
36. Korpela, E.; Liu, S.K. Endothelial perturbations and therapeutic strategies in normal tissue radiation damage. Radiat. Oncol. 2014, 9, 266. [CrossRef] [PubMed]

37. Wang, M.; Saha, J.; Hada, M.; Anderson, J.A.; Pluth, J.M.; O’Neill, P.; Cucinotta, F.A. Novel smad proteins localize to ir-induced double-strand breaks: Interplay between tgfbeta and atm pathways. Nucleic Acids Res. 2013, 41, 933-942. [CrossRef] [PubMed]

38. Saha, J.; Wang, M.; Cucinotta, F.A. Investigation of switch from atm to atr signaling at the sites of DNA damage induced by low and high let radiation. DNA Repair. (Amst.) 2013, 12, 1143-1151. [CrossRef] [PubMed]

39. Wang, M.; Saha, J.; Cucinotta, F.A. Smad7 foci are present in micronuclei induced by heavy particle radiation. Mutat. Res. 2013, 756, 108-114. [CrossRef] [PubMed]

40. Velalopoulou, A.; Tyagi, S.; Pietrofesa, R.A.; Arguiri, E.; Christofidou-Solomidou, M. The flaxseed-derived lignan phenolic secoisolariciresinol diglucoside (SDG) protects non-malignant lung cells from radiation damage. Int. J. Mol. Sci. 2015, 17. [CrossRef] [PubMed]

41. Fracica, P.J.; Knapp, M.J.; Crapo, J.D. Patterns of progression and markers of lung injury in rodents and subhuman primates exposed to hyperoxia. Exp. Lung Res. 1988, 14, 869-885. [CrossRef] [PubMed]

42. Vertrees, R.A.; McCarthy, M.; Solley, T.; Popov, V.L.; Roaten, J.; Pauley, M.; Wen, X.; Goodwin, T.J. Development of a three-dimensional model of lung cancer using cultured transformed lung cells. Cancer Biol. Ther. 2009, 8, 356-365. [CrossRef] [PubMed]

43. Vertrees, R.A.; Zwischenberger, J.B.; Boor, P.J.; Popov, V.; McCarthy, M.; Solley, T.N.; Goodwin, T.J. Cellular differentiation in three-dimensional lung cell cultures. Cancer Biol. Ther. 2008, 7, 404-412. [CrossRef] [PubMed]

44. Malkinson, A.M.; Dwyer-Nield, L.D.; Rice, P.L.; Dinsdale, D. Mouse lung epithelial cell lines-Tools for the study of differentiation and the neoplastic phenotype. Toxicology 1997, 123, 53-100. [CrossRef]

45. McDoniels-Silvers, A.L.; Herzog, C.R.; Tyson, F.L.; Malkinson, A.M.; You, M. Inactivation of both Rb and p53 pathways in mouse lung epithelial cell lines. Exp. Lung Res. 2001, 27, 297-318. [CrossRef] [PubMed]

46. Koch, C.J. A thin-film culturing technique allowing rapid gas-liquid equilibration (6s) with no toxicity to mammalian cells. Radiat. Res. 1984, 97, 434-442. [CrossRef] [PubMed]

47. Allen, C.B.; Schneider, B.K.; White, C.W. Limitations to oxygen diffusion and equilibration in in vitro cell exposure systems in hyperoxia and hypoxia. Am. J. Physiol. Lung Cell. Mol. Physiol. 2001, 281, L1021-L1027. [PubMed]

48. Lee, J.C.; Bhora, F.; Sun, J.; Cheng, G.; Arguiri, E.; Solomides, C.C.; Chatterjee, S.; Christofidou-Solomidou, M. Dietary flaxseed enhances antioxidant defenses and is protective in a mouse model of lung ischemia-reperfusion injury. Am. J. Physiol. Lung Cell. Mol. Physiol. 2008, 294, L255-L265. [CrossRef] [PubMed]

49. Christofidou-Solomidou, M.; Tyagi, S.; Pietrofesa, R.; Dukes, F.; Arguiri, E.; Turowski, J.; Grieshaber, P.A.; Solomides, C.C.; Cengel, K.A. Radioprotective role in lung of the flaxseed lignan complex enriched in the phenolic secoisolariciresinol diglucoside (SDG). Radiat. Res. 2012, 178, 568-580. [CrossRef] [PubMed]

50. Pietrofesa, R.A.; Velalopoulou, A.; Arguiri, E.; Menges, C.W.; Testa, J.R.; Hwang, W.T.; Albelda, S.M.; Christofidou-Solomidou, M. Flaxseed lignans enriched in secoisolariciresinol diglucoside prevent acute asbestos-induced peritoneal inflammation in mice. Carcinogenesis 2016, 37, 177-187. [CrossRef] [PubMed]

(C) 2016 by the authors; licensee MDPI, Basel, Switzerland. This article is an open access article distributed under the terms and conditions of the Creative Commons Attribution (CC-BY) license (http://creativecommons.org/licenses/by/4.0/). 